\title{
Speciation and Attenuation of Arsenic and Selenium at Coal Combustion By-Product Management Facilities
}

Annual Technical Progress Report

October 1, 2003 - September 30, 2004

Mr. Robert Patton

U.S. Department of Energy

National Energy Technology Laboratory

626 Cochrans Mill Road

PO Box 10940, MS 922-273C

Pittsburgh, PA 15236-0940

DOE Award Number: DE-FC26-02NT41590

Principal Investigators:

K. Ladwig, Electric Power Research Institute

B. Hensel, Natural Resource Technology, Inc.

D. Wallschlager, Trent University

L. Lee, Purdue University

I. Murarka, Ish Inc.

Submitted By:

Ken Ladwig

Electric Power Research Institute

3412 Hillview Avenue

Palo Alto, CA 94304 


\section{EPRI DISCLAIMER OF WARRANTIES AND LIMITATION OF LIABILITIES}

This document was prepared by the organization(s) named below as an account of work sponsored or cosponsored by the Electric Power Research Institute, inc. (EPRI). Neither EPRI, any member of EPRI, any cosponsor, the organization(s) below, nor any person acting on behalf of any of them:

(a) makes any warranty or representation whatsoever, express or implied, (i) with respect to the use of any information, apparatus, method, process, or similar item disclosed in this document, including merchantability and fitness for a particular purpose, or (ii) that such use does not infringe on or interfere with privately owned rights, including any party's intellectual property, or (iii) that this document is suitable to any particular user's circumstance; or

(b) assumes responsibility for any damages or other liability whatsoever (including any consequential damages, even if EPRI or any epri representative has been advised of the possibility of such damages) resulting from your selection or use of this document or any information, apparatus, method, process, or similar item disclosed in this document.

\section{DOE DISCLAIMER}

This report was prepared as an account of work sponsored by an agency of the United States Government. Neither the United States Government, nor any agency thereof, nor any of their employees, makes any warranty, express or implied, or assumes any legal liability or responsibility for the accuracy, completeness, or usefulness of any information, apparatus, product, or process disclosed or represents that its use would not infringe privately owned rights. Reference herein to any specific commercial product, process, or service by trade name, trademark, manufacturer, or otherwise does not necessarily constitute or imply its endorsement, recommendation, or favoring by the United States Government or any agency thereof. The views and opinions of authors expressed herin do not necessarily state or reflect those of the United States Government or any agency thereof. 


\section{ABSTRACT}

Field leachate samples are being collected from coal combustion product (CCP) management sites from several geographic locations in the United States to provide broad characterization of major and trace constituents in the leachate. In addition, speciation of arsenic, selenium, chromium, and mercury in the leachates is being determined. Through 2003, 35 samples were collected at 14 sites representing a variety of CCP types, management approaches, and source coals. Samples have been collected from leachate wells, leachate collection systems, drive-point piezometers, lysimeters, the ash/water interface at impoundments, impoundment outfalls and inlets, and seeps. Additional sampling at 23 sites has been conducted in 2004 or is planned for 2005.

First-year results suggest distinct differences in the chemical composition of leachate from landfills and impoundments, and from bituminous and subbituminous coals. Concentrations of most constituents were generally higher in landfill leachate than in impoundment leachate. Sulfate, sodium, aluminum, molybdenum, vanadium, cadmium, mercury and selenium concentrations were higher in leachates for ash from subbituminous source coal. Calcium, boron, lithium, strontium, arsenic, antimony, and nickel were higher for ash from bituminous source coal. These variations will be explored in more detail when additional data from the 2004 and 2005 samples become available. 


\section{CONTENTS}

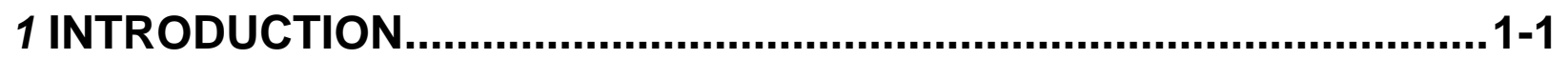

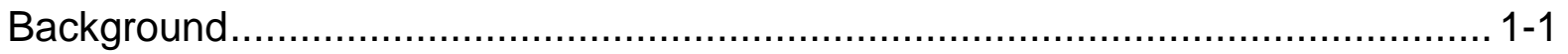

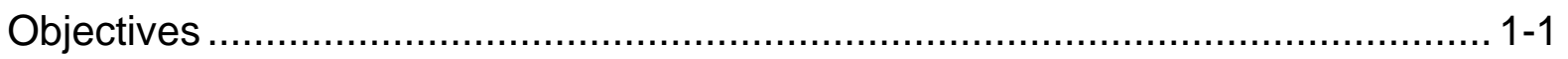

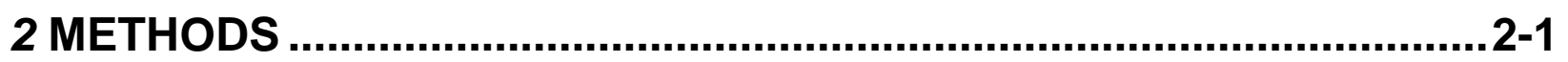

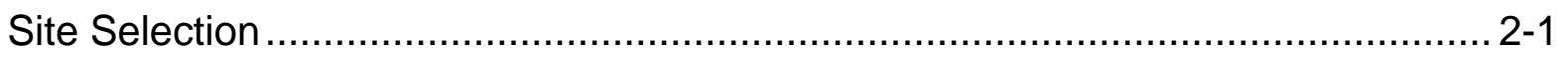

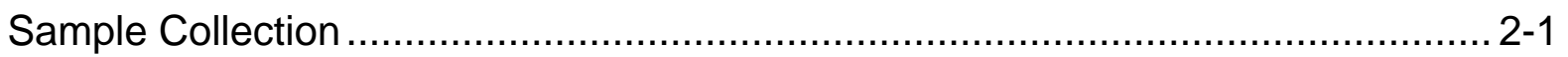

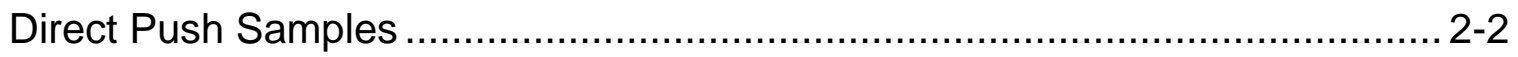

Leachate Wells, Lysimeters, and Leachate Collection Systems...................... 2-2

Surface Water and Sluice Samples ......................................................... 2-3

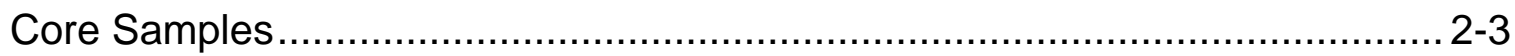

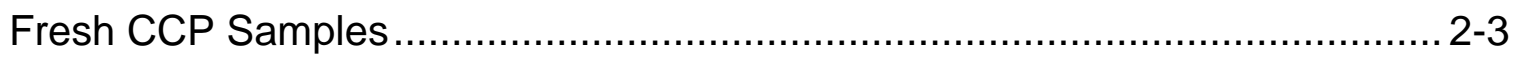

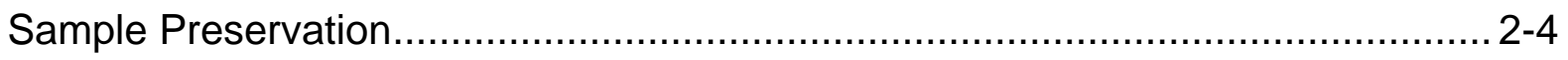

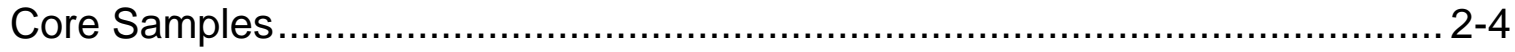

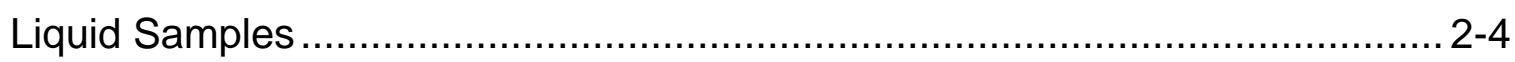

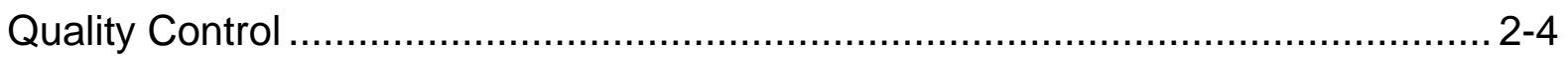

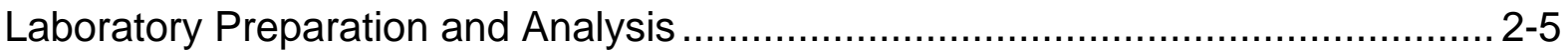

Trace Element Determinations by Double-Focusing ICP-MS (DF-ICP-MS) ...... 2-5

Determination of Total Arsenic, Selenium, and Chromium by Dynamic Reaction

Cell-ICP-MS (DRC-ICP-MS)................................................................ 2-6

Arsenic and Selenium Speciation by lon-Chromatography Anion Self-

Regenerating Suppressor ICP-MS (IC-ASRS-ICP-MS) ............................... 2-7

Chromium Speciation by lon-Chromatography Anion Self-Regenerating

Suppressor DRC-ICP-MS (IC-ASRS-DRC-ICP-MS) ................................. 2-9

Mercury Speciation Methods ............................................................... 2-11

Ancillary Parameters ................................................................................... 2-11

3 SAMPLE SUMMARY .....................................................................

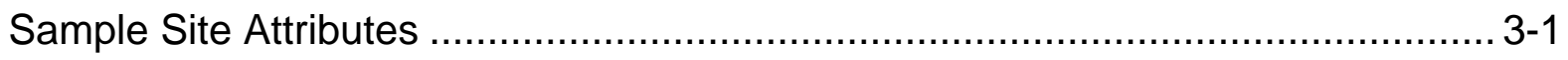

42003 RESULTS ........................................................................... 4-1

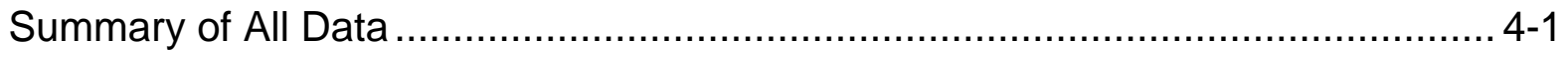

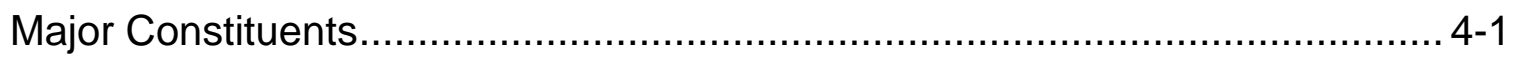

Minor and Trace Elements ................................................................... 4-2

Comparison of Ash Leachate Concentrations to Site Attributes ......................... 4-5

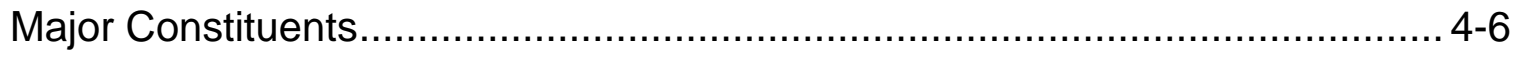

Minor and Trace Elements ............................................................... 4-9 


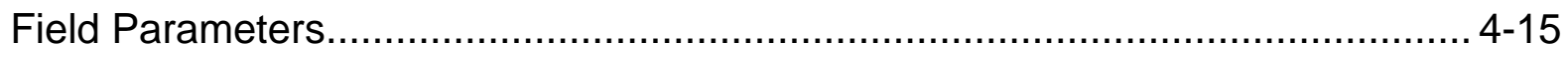

Leachate Variability as a Function of Sample Point ......................................... 4-17

5 REFERENCES................................................................................. 5-1

A Appendix ................................................................................... A-1 Discrepancies in the Mass Balance of Arsenic, Selenium and Chromium Species A-1 Irreversible Formation of Precipitates in the Speciation Samples.....................A-1 Presence of Species that Cannot be Analyzed Using Current Methods.............A-2 Systematic Analytical Bias..................................................................... Interpretation of the Reported Speciation Patterns ..........................................

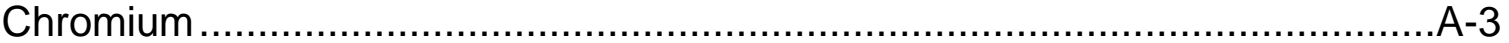

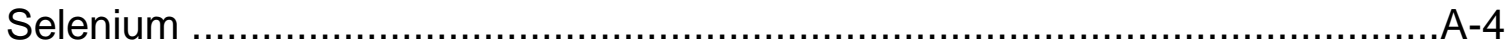

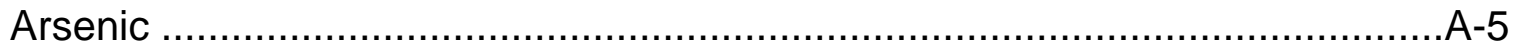




\section{EXECUTIVE SUMMARY}

\section{Introduction}

Coal combustion products (CCPs) - fly ash, bottom ash, boiler slag, and flue gas desulfurization (FGD) solids - are derived primarily from incombustible mineral matter in coal and sorbents used to capture gaseous components from the flue gas, and as such contain a wide range of inorganic constituents. Concentrations of these constituents in CCPs and their leachability can vary widely by coal type and combustion/collection processes. Since CCP leachates commonly have neutral to alkaline $\mathrm{pH}$, mobility of heavy metal cations such as lead and cadmium is limited. Other constituents, such as arsenic and selenium, typically occur as oxyanions, which are more mobile than metal cations under alkaline $\mathrm{pH}$ conditions. Knowledge of factors controlling the leachability and mobility in groundwater of the different constituents is critical to development of appropriate CCP management practices, including treatment of ash ponds and groundwater management at dry disposal sites.

Previous research has indicated that arsenic and selenium are present in laboratory-generated ash leachates. Only limited, mostly site-specific, work has been performed to characterize the concentration and of these constituents in field leachate. Furthermore, little work has been performed to determine the species of arsenic and selenium present in field leachates, which may have a significant effect on their release from the ash and mobility in groundwater.

The objectives of this research are to characterize CCP leachate samples collected in the field, including speciation of arsenic, selenium, chromium, and mercury. The research will provide fundamental data necessary for evaluation of the effects of CCP management methods on leachate quality and of the long-term fate of inorganic constituents at CCP management sites.

\section{Approach}

Preliminary information on power plant configurations, emission controls, and CCP management methods was assembled for 274 power plants operated by 32 utilities. A subset of these management sites was selected for sampling, based on individual site considerations as well as development of a range of site types representative of the industry.

As of the end of 2003, 35 leachate samples were collected at 14 sites. The 2003 samples included 16 from landfills and 19 from impoundments. Twenty-eight of these samples were from coal ash management sites, and seven were from sites where FGD solids, FGD solids stabilized with fly ash, or spray dryer ash were managed. Half (18) of the samples came from sites that received CCP from bituminous coal, 11 samples were from sites that received CCP derived from subbituminous coal, and six were derived from mixed coals.

Leachate samples were collected from available access points, including leachate wells, lysimeters, leachate collection systems, sluice lines, direct push drive-points, core samples, and ponds. The goal was to obtain undiluted samples representative of CCP leachate. Samples were collected by a variety of methods, depending on sample type and accessibility. In all cases, the samples were filtered in-line and collected directly into bottles containing appropriate preservatives. Speciation samples were not acid-preserved, instead they were cryofrozen in the 
field by submerging the sample in a bath of liquid nitrogen. Samples were analyzed using stateof-the-art analytical methods, resulting in detection limits of less than a part per billion for most trace constituents and less than a part per trillion for mercury.

\section{First Year Results}

\section{Concentration Ranges in CCP Leachate}

The $\mathrm{pH}$ of the leachate samples was neutral to strongly alkaline. Leachate from landfills and ash derived from subbituminous coal tended to be more alkaline than impoundment/bituminous coal leachate. Dissolved oxygen and ORP were lower in landfill samples than in impoundment sanmples.

The anion chemistry of most samples was dominated by sulfate (median concentration of $1,370 \mathrm{mg} / \mathrm{L}$ ), while cation chemistry of most samples was dominated by calcium (median $231 \mathrm{mg} / \mathrm{L}$ ) and/or sodium (median $70 \mathrm{mg} / \mathrm{L}$ ). Sodium was typically dominant in samples from plants that burned subbituminous or a mixture of subbituminous and bituminous coal, and calcium was typically dominant in samples from plants that burned bituminous or a mixture of bituminous and subbituminous coals.

In most cases, the range of concentrations for minor and trace elements spanned two to three orders of magnitude. Boron had the highest maximum $(102,000 \mu \mathrm{g} / \mathrm{L})$ and median $(8,855 \mu \mathrm{g} / \mathrm{L})$ concentration of the minor and trace elements. Other minor and trace elements with median concentrations greater than $100 \mu \mathrm{g} / \mathrm{L}$ were aluminum, silica, strontium, and molybdenum. Elements with median concentrations less than $1 \mu \mathrm{g} / \mathrm{L}$ included chromium, lead, mercury, silver, and thallium. The maximum concentrations of beryllium, silver, and mercury were lower than $5 \mu \mathrm{g} / \mathrm{L}$.

Total arsenic concentrations ranged from 3 to $238 \mu \mathrm{g} / \mathrm{L}$, with a median of $24 \mu \mathrm{g} / \mathrm{L}$. Five samples, from three different sites, had an arsenic concentration greater than $100 \mu \mathrm{g} / \mathrm{L}$. Conversely, five samples, from three different sites, had arsenic concentration lower than $10 \mu \mathrm{g} / \mathrm{L}$.

Total selenium concentration exhibited a larger range than arsenic, from 0.3 to $2,360 \mu \mathrm{g} / \mathrm{L}$, although the median selenium concentration of $15 \mu \mathrm{g} / \mathrm{L}$ was lower than for arsenic. Three samples from two sites had concentrations greater than $1,000 \mu \mathrm{g} / \mathrm{L}$, and five samples from four additional sites had concentrations greater than $100 \mu \mathrm{g} / \mathrm{L}$. Fourteen samples had a selenium concentration lower than $10 \mu \mathrm{g} / \mathrm{L}$. These fourteen samples included all five of the arsenic samples with concentration lower than $10 \mu \mathrm{g} / \mathrm{L}$, and three of the five arsenic samples with concentration greater than $100 \mu \mathrm{g} / \mathrm{L}$.

Speciation data for arsenic, selenium, and, to a lesser extent, chromium exhibited discrepancies between the sum of species and total concentrations. One possible factor contributing to this discrepancy was the formation of precipitates in some of the sample bottles during storage. A priority of the 2004/2005 field and laboratory work is determining the causes and developing solutions to resolve the species discrepancy. 


\section{$\underline{\text { Effects of Management Method and Source Coal Type on Leachate Concentrations }}$}

Concentrations of all major ions, except chloride, were higher in landfill leachate than in impoundment leachate. There was also a difference in major ion composition by source coal type. Sulfate and sodium concentrations tended to be higher when the source coal was subbituminous, rather than bituminous. Conversely, calcium concentrations were higher when the source coal was bituminous.

Source coal type also affected minor and trace constituent concentrations. Some of the elements that had higher concentration in leachate from subbituminous coals included aluminum, mercury, selenium, and vanadium, while leachate from bituminous coals often had higher concentrations of lithium, strontium, antimony, and nickel.

These observations are based on a relatively limited set of 35 leachate samples collected through 2003. Some of these relationships may become clearer, or may change, after analysis of the full sample set is completed in 2005. 


\section{1 \\ INTRODUCTION}

\section{Background}

Coal combustion products (CCPs) — fly ash, bottom ash, boiler slag, and flue gas desulfurization (FGD) solids - are derived primarily from incombustible mineral matter in coal and sorbents used to capture gaseous components from the flue gas, and as such contain a wide range of inorganic constituents. Concentrations of these constituents in CCPs and their leachability can vary widely by coal type and combustion/collection processes. Since CCP leachates commonly have neutral to alkaline $\mathrm{pH}$, mobility of heavy metal cations such as lead and cadmium is limited. Other constituents, such as arsenic and selenium, typically occur as oxyanions, which are more mobile than metal cations under alkaline $\mathrm{pH}$ conditions. Knowledge of factors controlling the leachability and mobility in groundwater of the different constituents is critical to development of appropriate CCP management practices, including treatment of ash ponds and groundwater management at dry disposal sites.

Previous research has indicated that arsenic and selenium concentrations in laboratory-generated ash leachates generally range from less than $1 \mu \mathrm{g} / \mathrm{L}$ to about $800 \mu \mathrm{g} / \mathrm{L}$ (EPRI, 2003a). Arsenic concentrations higher than $1,000 \mu \mathrm{g} / \mathrm{L}$ in ash porewater have been associated with pyrite oxidation in areas where coal mill rejects are concentrated (EPRI, 2003b). Only limited work has been done to determine species of arsenic and selenium present in field leachates. The species of arsenic and selenium present in the leachate will have a significant effect on their release from the ash and mobility in groundwater (EPRI, 1994; EPRI, 2000; EPRI, 2004).

\section{Objectives}

The objectives of this research are to characterize CCP leachate samples collected in the field, including speciation of arsenic, selenium, chromium, and mercury. The research will provide fundamental data necessary for evaluation of the effects of CCP management methods on leachate quality and of the long-term fate of inorganic constituents at CCP management sites. 


\section{2 \\ METHODS}

\section{Site Selection}

Preliminary information on power plant configurations, emission controls, and CCP management methods was assembled for 274 power plants operated by 32 utilities. A subset of management sites was selected from this list, based on individual site considerations as well as development of a range of site types representative of the industry.

Individual sites were evaluated based on:

- utility interest in participation;

- availability of leachate sampling points;

- whether or not the site was believed to have leachate in sufficient quantities for sampling (i.e., wet CCP).

A distribution of sites was selected to encompass:

- a broad geographic distribution;

- a range of CCP types (fly ash, bottom ash, flue gas desulfurization solids);

- a representative distribution of CCP management methods (landfills and impoundments, active and inactive);

- coal types from various coal source regions;

- varying plant characteristics

- boiler types;

- particulate controls;

- NOx controls;

- $\mathrm{SO}_{2}$ controls;

- units with and without flue gas conditioning.

Based on these criteria, $37 \mathrm{CCP}$ sites in 16 states were selected for possible sampling. Field sampling was initiated in 2003 and will continue into 2005.

\section{Sample Collection}

Leachate samples were collected from several access points, including leachate wells, lysimeters, leachate collection systems, sluice lines, direct push drive-points, core samples, and ponds. The goal was to obtain undiluted samples representative of CCP leachate. Samples were collected by a variety of methods, depending on sample type and accessibility. In all cases, the samples were filtered in-line and collected directly into bottles containing appropriate preservatives. 


\section{Direct Push Samples}

Shallow porewater samples were collected from within the CCP using two direct-push methods: drive-point piezometers and t-handle probes. The drive-point sampler consisted of a $3 / 4$-inch stainless steel drive-point piezometer driven into the CCP material to the desired sampling depth using a slide hammer. A $1 / 2$-inch plastic tube was attached to the drive-point and threaded through $3 / 4$-inch steel riser pipe. The sample was extracted by sliding chemically-inert $1 / 4$-inch FEP tubing through the $1 / 2$-inch tubing down the riser pipe and into the screened portion of the stainless steel drive-point. The FEP tubing was then attached to a peristaltic pump via a short length of clean flexible silicone pump tubing.

The t-handle probe is composed of a single, thin-diameter stainless steel tube that has small manufactured slots cut into the tip for sample collection. A short plastic netting was placed over the tip of the probe just prior to installation to reduce intake of fine-grained sediments. Each t-handle probe was hand-driven into the CCP to a depth of as much as six feet. The top of the t-handle was then connected to a plastic syringe to initiate water flow. Once water flow was established, a short piece of silicone tubing was used to connect $1 / 4$-inch FEP tubing to the top of the probe. The $1 / 4$-inch FEP tubing was then connected to a peristaltic pump via a short length of clean flexible silicone pump tubing.

\section{Leachate Wells, Lysimeters, and Leachate Collection Systems}

Leachate wells, lysimeters, and leachate collection systems collect deep porewater within or immediately beneath the CCP. The leachate wells sampled for this study were installed by the utilities for the purpose of monitoring leachate quality. These devices, which consist of smalldiameter (2- to 4-inch) polyvinylchloride (PVC) or stainless steel pipe with slotted screens at the bottom, are installed vertically in the CCP. Lysimeters were also installed to monitor leachate quality, and differ from leachate wells in that they collect porewater beneath the CCP. ${ }^{1}$

Lysimeters are large collection devices, usually lined with plastic and filled with sand or gravel. Leachate percolates through the CCP and into the lysimeter, where it is removed from the sand or gravel through piping that extends to land surface. Leachate collection systems are installed to drain leachate from a CCP management unit, thus preventing head build-up on the liner. These systems typically consist of large-diameter (at least 4-inch) slotted plastic pipe embedded in a sand or gravel layer above the liner. Samples may be collected at clean-out ports where the pipes emerge from beneath the fill deposit, or at the tanks where the collected leachate is stored prior to processing.

Whenever possible, low-flow methods were employed while sampling leachate wells to minimize disturbances within the sampling zone. Low-flow sampling is accomplished by pumping water at a rate that is compatible with the rate of recovery for the well (or similar sample point) and the matrix being sampled, using methods that do not cause water surging within the well (Puls and Barcelona, 1995). Purging and sampling were performed with a

\footnotetext{
${ }^{1}$ In a typical installation, lysimeters are installed beneath liners to monitor liner performance. However, the lysimeters monitored for this study were installed immediately beneath the CCP.
} 
peristaltic pump or, for deeper wells, a bladder pump. In a few cases with restricted access, a hand-operated Waterra ${ }^{\mathrm{TM}}$ pump or bailer was used to retrieve samples. ${ }^{2}$

When low-flow sampling methods could not be performed, either "minimum purge" sampling or "maximum purge" sampling was used. Minimum purge sampling was used in a few instances where CCP surrounding the well had relatively low permeability and would not achieve a stable drawdown during low-flow pumping. This method was only used on wells that were constructed of PVC. Maximum purge sampling was used in the few instances where an existing well was constructed of stainless steel or any other metal, which may have influenced the water sample, if the well could not support low-flow sampling flow rates. In these instances, the well was completely purged the day before sampling.

Lysimeters and leachate collection systems were sampled by lowering the peristaltic pump FEP tubing to the water surface. However, in some cases, the depth to water was too great for sampling with a peristaltic pump, in which case the Waterra pump or a bladder pump connected to Teflon ${ }^{\mathrm{TM}}$ tubing was used to withdraw the sample.

\section{Surface Water and Sluice Samples}

Surface water samples were collected from ash or FGD ponds. Typically, the pond samples were accessed from structures that extended above the water or by boat. In either case, $1 / 4$-inch FEP tubing was lowered into the water and connected to a peristaltic pump via a short length of clean flexible silicone tubing. Samples were collected from different depths by attaching the FEP tubing to a clean water level indicator and lowering the tubing to the desired depth. In most cases, samples were collected from as near the ash/water interface as possible. Sluice and outfall samples were collected directly from the sluice pipe or outfall structure in a clean plastic container or plastic dip cup sampler. FEP tubing connected to a peristaltic pump via a short length of clean flexible silicone tubing was lowered into the container and the sample was collected.

\section{Core Samples}

Core samples were collected at selected sites where porewater samples could not otherwise be obtained. A hollow-stem auger drill rig was used to advance a lined split-spoon sampler or core barrel sampler into the CCP deposit. Typically, a preliminary borehole was drilled in advance of the sample borehole in order to log the intervals where the wettest CCP was encountered, and the sampler was then advanced in a second, adjacent borehole to the selected depth. Porewater was then extracted from the core in the laboratory.

\section{Fresh CCP Samples}

In addition to the leachate samples described above, fresh samples of CCP were collected from most of the source power plants. These samples were collected by utility personnel directly from the ash hopper, or along the FGD process line, in 5-gallon metal or plastic buckets. Results of analysis of these samples will be described in another EPRI report.

\footnotetext{
${ }^{2}$ Newall, J., Groundwater Monitoring with the Waterra Inertial Pump, http://www.waterra.com/pages/techpapers/TechA(Groundwater\%20Monitoring)/techA1.html
} 


\section{Sample Preservation}

\section{Core Samples}

Core samples for leachate analyses were collected in clear, large-diameter, plastic or Teflon liners. After the liner tubes were recovered, the ends were cut so that no air volume or disturbed sample was included in the tube, and the ends of the tubes were sealed with Parafilm ${ }^{\mathrm{TM}}$, plastic end caps, and tape. Tubes were stored in coolers with dry ice for shipment to the laboratory via overnight delivery. Leachate was extracted from wet ash samples in the laboratory by centrifuge, then filtered and preserved as described below for liquid samples.

\section{Liquid Samples}

Liquid leachate samples were filtered in the field and then split for the individual analyses. A $0.45 \mu \mathrm{m}$ filter was used for all liquid samples, and turbid samples were prefiltered using either a 1.0 or $5.0 \mu \mathrm{m}$ filter.

There are two general approaches for preservation of speciation samples: acid preservation and freezing, each with drawbacks. Acid preservation approaches have limited holding times, and require prior knowledge of redox conditions at the sample point for selection of the appropriate preservation fluid - reducing conditions are particularly problematic. Freezing is not commonly used and there may be nuances to this method that have not been explored. Since prior data on redox conditions were typically not available for this sampling, the freezing approach was employed. Samples for arsenic, selenium, and chromium speciation were immediately cryofrozen in the field using liquid nitrogen, and then kept frozen on dry ice with minimal air contact until analysis to prevent changes in speciation by oxidation.

Separate water samples were collected for the determination of total mercury (THg), dissolved mercury (DHg), total methylmercury (TMeHg), dissolved methylmercury (DMeHg), and dimethylmercury (DMM). New tubing, filter materials, and sampling containers were used to prevent sample contamination. Samples for $\mathrm{DHg}$ and $\mathrm{DMeHg}$ were collected using in-line filtration. All samples except the DMM samples were preserved in the field with $\mathrm{HCl}$. DMM was purged from the collected water samples with an argon stream in the field, and collected on Carbotrap ${ }^{\mathrm{TM}}$ adsorbent tubes. These tubes were dried with an argon stream opposite to the adsorption direction, sealed, and kept cold and dark until analysis. All collected samples were double-bagged to prevent contamination, and clean sampling protocols (consistent with EPA method 1631) were followed.

Field parameters including $\mathrm{pH}$, conductivity, redox potential, and temperature were measured using an in-line flow cell and/or multi-probe sample collected during sampling.

\section{Quality Control}

A suite of quality control (QC) samples were analyzed for most sample trips, which consisted of sample and matrix spike duplicates, blanks, and reference materials as appropriate and available. Final data reported may be corrected to reflect the results of the QC samples to yield the most accurate and precise result possible. 


\section{Laboratory Preparation and Analysis}

\section{Trace Element Determinations by Double-Focusing ICP-MS (DF-ICP-MS)}

A Thermo Finnigan Element II double-focusing inductively coupled plasma-mass spectrometer (DF-ICP-MS) in medium resolution mode was used to determine 22 elements of interest (Table 2-1). Each sample was analyzed at three different dilutions $(500 x, 100 x$, and 20x) to cover the different concentration ranges of the elements. Due to the high salt load of the samples, a dilution factor of less than 20x might lead to instrument damage and was therefore avoided; however, all field blanks and equipment blanks were analyzed undiluted because they did not contain salts. According to the typical concentrations of different elements, the 500x diluted samples were analyzed for lithium, boron, aluminum, silica, iron, strontium, and molybdenum; the 100x diluted samples for lithium, beryllium, boron, aluminum, vanadium, chromium, manganese, iron, cobalt, nickel, copper, zinc, strontium, molybdenum, silver, cadmium, antimony, barium, thallium, lead, and uranium; and the 20x diluted samples for lithium, beryllium, aluminum, vanadium, chromium, manganese, iron, cobalt, nickel, copper, zinc, molybdenum, silver, cadmium, antimony, barium, thallium, lead, and uranium. If one element was analyzed at more than one dilution, the result obtained with the lowest dilution factor under consideration of the calibrated range was reported.

At least two isotopes for each element (if possible) were measured to verify the absence of spectrometric interferences. Scandium, indium, rhodium, and germanium were used as internal standards to monitor and correct instrument drift and sample uptake effects. All measured and control isotopes are listed in Table 2-1. Typically, the results obtained for the measured and the control isotope were identical (within the analytical uncertainty); however, some exceptions are explained in the paragraph below. Typical instrumental detection limits (IDLs) are also listed in Table 2-1, calculated as three times the standard deviation of four instrument blanks $\left(1 \% \mathrm{HNO}_{3}\right)$. The method detection limit (MDL) was estimated as the IDL times the applicable dilution factor of the analyzed sample. The IDL/MDL was determined with each analytical run and varied slightly depending on the instrument performance on that day. All data reported were instrument-blank corrected. For quality control purposes, a certified reference material (CRM) was analyzed at two different dilutions per analytical run to confirm an accurate calibration. Per sample batch (usually one per sampling trip) one randomly selected sample was analyzed in duplicate and spiked and analyzed in duplicate to assess accuracy and reproducibility.

For some of the elements listed in Table 2-1, the results obtained for the measured and the control isotope did not match. For some elements (e.g., silver, zinc, thallium), the analyte concentrations in many samples were only 5 to 10 times the detection limit, so that analytical uncertainty or insufficient number of samples with detectable concentrations prevented a meaningful isotope comparison. In other cases, the control isotope had a very low abundance and although the sample concentration was very well detectable for the main isotope, the quantification by the minor isotope was impaired by low signal intensities (e.g., ${ }^{50} \mathrm{~V}$; natural abundance $0.25 \%$ ). Also, in the used concentration range, ${ }^{6} \mathrm{Li}$ was not detected in medium resolution mode by the instrument; therefore, it was not used for confirming ${ }^{7} \mathrm{Li}$.

In medium (or even high) resolution mode, some isobaric and polyatomic interferences could not be resolved: ${ }^{58} \mathrm{Ni}$ was not separated from ${ }^{58} \mathrm{Fe}$ in medium resolution mode (required resolution $\sim 30,000$; available resolution $\sim 4,000)$. As the ${ }^{58} \mathrm{Fe}$ abundance is only $0.28 \%$, the associated 
error is normally negligible; however, if the iron concentrations are extremely high, as in some of the analyzed samples, ${ }^{58} \mathrm{Ni}$ will be affected. Also, ${ }^{87} \mathrm{Sr}$ was also not separated from ${ }^{87} \mathrm{Rb}$ in medium resolution mode (required resolution $\sim 300,000$ ); however, the error in this case is not negligible as ${ }^{87} \mathrm{Rb}$ has an abundance of $27.8 \%$. If ${ }^{87} \mathrm{Sr}$ is corrected for ${ }^{87} \mathrm{Rb}$, both ${ }^{87} \mathrm{Sr}$ and ${ }^{88} \mathrm{Sr}$ yield identical results. For cadmium, both ${ }^{111} \mathrm{Cd}$ and ${ }^{114} \mathrm{Cd}$ were interfered with by $\mathrm{MoO}$ (required resolution $\sim 100 \mathrm{~K}$ and $\sim 80 \mathrm{~K}$, respectively); in addition, ${ }^{114} \mathrm{Cd}$ was also affected by an isobaric interference of ${ }^{114} \mathrm{Sn}$. Based on those considerations, ${ }^{110} \mathrm{Cd}$ was used for quantification. Generally, as spectroscopic interferences are normally positive, in the event that two isotopes yield a different result, the lower concentration will most likely be the uninterfered and therefore the correct result.

Table 2-1

Trace Metals by DF-ICP-MS

\begin{tabular}{|c|c|c|c|c|}
\hline Element & $\begin{array}{l}\text { Measured } \\
\text { Isotope }\end{array}$ & $\begin{array}{l}\text { Control } \\
\text { Isotope }\end{array}$ & $\begin{array}{l}\text { Isotopes } \\
\text { Agree? }\end{array}$ & Typical IDL [ppb] \\
\hline Aluminum & ${ }^{27} \mathrm{Al}$ & monoisotopic & & 0.08 \\
\hline Antimony & ${ }^{121} \mathrm{Sb}$ & ${ }^{123} \mathrm{Sb}$ & $\mathrm{Y}$ & 0.005 \\
\hline Barium & ${ }^{136} \mathrm{Ba}$ & ${ }^{137} \mathrm{Ba}$ & $\mathrm{Y}$ & 0.1 \\
\hline Beryllium & ${ }^{9} \mathrm{Be}$ & monoisotopic & & 0.01 \\
\hline Boron & ${ }^{10} \mathrm{~B}$ & ${ }^{11} \mathrm{~B}$ & $\mathrm{Y}$ & 0.07 \\
\hline Cadmium & ${ }^{110} \mathrm{Cd}$ & ${ }^{111} \mathrm{Cd},{ }^{114} \mathrm{Cd}$ & $\mathrm{N}$ & 0.005 \\
\hline Chromium & ${ }^{53} \mathrm{Cr}$ & ${ }^{52} \mathrm{Cr}$ & $\mathrm{Y}$ & 0.01 \\
\hline Cobalt & ${ }^{59} \mathrm{Co}$ & monoisotopic & & 0.001 \\
\hline Copper & ${ }^{65} \mathrm{Cu}$ & ${ }^{63} \mathrm{Cu}$ & $\mathrm{Y}$ & 0.01 \\
\hline Iron & ${ }^{56} \mathrm{Fe}$ & ${ }^{57} \mathrm{Fe}$ & $\mathrm{Y}$ & 0.05 \\
\hline Lead & ${ }^{208} \mathrm{~Pb}$ & ${ }^{206} \mathrm{~Pb},{ }^{207} \mathrm{~Pb}$ & $\mathrm{Y}$ & 0.005 \\
\hline Lithium & ${ }^{7} \mathrm{Li}$ & not available & & 0.05 \\
\hline Manganese & ${ }^{55} \mathrm{Mn}$ & monoisotopic & & 0.005 \\
\hline Molybdenum & ${ }^{98} \mathrm{Mo}$ & ${ }^{95} \mathrm{Mo}$ & $\mathrm{Y}$ & 0.01 \\
\hline Nickel & ${ }^{60} \mathrm{Ni}$ & ${ }^{58} \mathrm{Ni}$ & $\begin{array}{l}\mathrm{Y} \text { (except in samples } \\
\text { with high Fe } \\
\text { concentrations ) }\end{array}$ & $0.03-0.05$ \\
\hline Silica & ${ }^{28} \mathrm{Si}$ & ${ }^{30} \mathrm{Si}$ & Y & $0.3-0.6$ \\
\hline Silver & ${ }^{107} \mathrm{Ag}$ & ${ }^{109} \mathrm{Ag}$ & $\begin{array}{l}\text { Y? (concentrations } \\
\text { close to MDL) }\end{array}$ & 0.01 \\
\hline Strontium & ${ }^{88} \mathrm{Sr}$ & ${ }^{87} \mathrm{Sr}$ & $\begin{array}{l}\text { Y (after Rb correction } \\
\text { of }{ }^{87} \mathrm{Sr} \text { ) }\end{array}$ & 0.01 \\
\hline Thallium & ${ }^{205} \mathrm{Tl}$ & ${ }^{203} \mathrm{Tl}$ & $\begin{array}{l}\text { Y? (concentrations } \\
\text { close to MDL) }\end{array}$ & 0.005 \\
\hline Uranium & ${ }^{238} \mathrm{U}$ & not available & no interferences & 0.0005 \\
\hline Vanadium & ${ }^{51} \mathrm{~V}$ & ${ }^{50} \mathrm{~V}$ & $\mathrm{~N}$ & 0.005 \\
\hline Zinc & ${ }^{66} \mathrm{Zn}$ & ${ }^{68} \mathrm{Zn}$ & $\begin{array}{l}\text { Y? (concentrations } \\
\text { close to MDL) }\end{array}$ & 0.1 \\
\hline
\end{tabular}

\section{Determination of Total Arsenic, Selenium, and Chromium by Dynamic Reaction Cell-ICP-MS (DRC-ICP-MS)}

Total arsenic, selenium, and chromium were determined by a Perkin-Elmer DRC II ICP-MS in dynamic reaction cell (DRC) mode using ammonia as the reaction gas for the determination of arsenic, and a methane/ammonia mixture for selenium and chromium. Although chromium can be measured reliably by DF-ICP-MS, the results obtained by DRC-ICP-MS were reported for 
consistency reasons, as the speciation of chromium was also performed on this instrument. The chromium results obtained by DRC-ICP-MS and DF-ICP-MS were in good agreement.

Instrument settings and detection limits, calculated as three times the standard deviation of four instrument blanks $\left(1 \% \mathrm{HNO}_{3}\right)$, are reported in Table 2-2.

Arsenic is monoisotopic and therefore has no confirmation isotope; however, ${ }^{77} \mathrm{Se}$ was measured to compensate for the potential interference of ${ }^{40} \mathrm{Ar}{ }^{35} \mathrm{Cl}$ on ${ }^{75} \mathrm{As}$. The major isotope ${ }^{80} \mathrm{Se}$ was used for quantification of selenium. As mentioned before, in the absence of interferences, all isotopes of an element should yield the same result, and for most of the samples this was achieved with the current instrument settings. However in the case of low selenium and high salt concentrations, the three measured selenium isotopes showed different results. In these cases, the result was flagged in the results table (Table 4-1). ${ }^{53} \mathrm{Cr}$ was measured as a control isotope for ${ }^{52} \mathrm{Cr}$, and the two chromium isotopes generally agreed very well. Rhodium and indium were used as internal standards. A certified reference material was analyzed with each analytical run to confirm accurate calibration, and a matrix duplicate, a matrix spike, and a matrix spike duplicate were analyzed with each batch.

Table 2-2

Method Parameters for Total As, Se, and Cr Determinations by DRC-ICP-MS

\begin{tabular}{|l|l|l|}
\hline & Arsenic & Selenium + Chromium \\
\hline Measured masses & ${ }^{75} \mathrm{As}$ & ${ }^{80} \mathrm{Se},{ }^{52} \mathrm{Cr}$ \\
\hline Monitor masses & ${ }^{77} \mathrm{Se},{ }^{78} \mathrm{Se},{ }^{82} \mathrm{Se}$ & ${ }^{78} \mathrm{Se},{ }^{82} \mathrm{Se},{ }^{53} \mathrm{Cr}$ \\
\hline Dwell time & $200 \mathrm{~ms} /$ isotope & $200 \mathrm{~ms} /$ isotope \\
\hline Reaction gas & $\mathrm{NH}_{3}=0.35 \mathrm{ml} / \mathrm{min}$ & $\begin{array}{l}\mathrm{NH}_{3}=0.3 \mathrm{ml} / \mathrm{min} \\
\mathrm{CH}_{4}=0.45 \mathrm{ml} / \mathrm{min}\end{array}$ \\
\hline Bandpass & $\mathrm{RPq}=0.6$ & $\mathrm{RPq}=0.6$ \\
\hline Typical IDL $[\mathrm{ppb}]$ & 0.01 & $0.01\left({ }^{80} \mathrm{Se}\right), 0.01\left({ }^{52} \mathrm{Cr}\right)$ \\
\hline
\end{tabular}

\section{Arsenic and Selenium Speciation by Ion-Chromatography Anion Self- Regenerating Suppressor ICP-MS (IC-ASRS-ICP-MS)}

As(III), As(V), Se(IV), and Se(VI) were determined simultaneously by IC-ASRS-ICP-MS (Wallschläger and Roehl, 2001; Wallschläger et al., 2005) using a Dionex ion-chromatography system with anion self-regenerating suppressor (ASRS) coupled to a Perkin-Elmer DRC II. Method parameters are listed in Table 2-3. The ICP-MS was used in standard mode as the interfering anions are chromatographically separated in time from the analytes (Figures 2-1 and 2-2). Typical achieved MDLs were $0.1 \mathrm{ppb}$ per species. In addition to the species mentioned above, any other unidentified anionic species such as soluble As-S compounds can be determined by this method. 


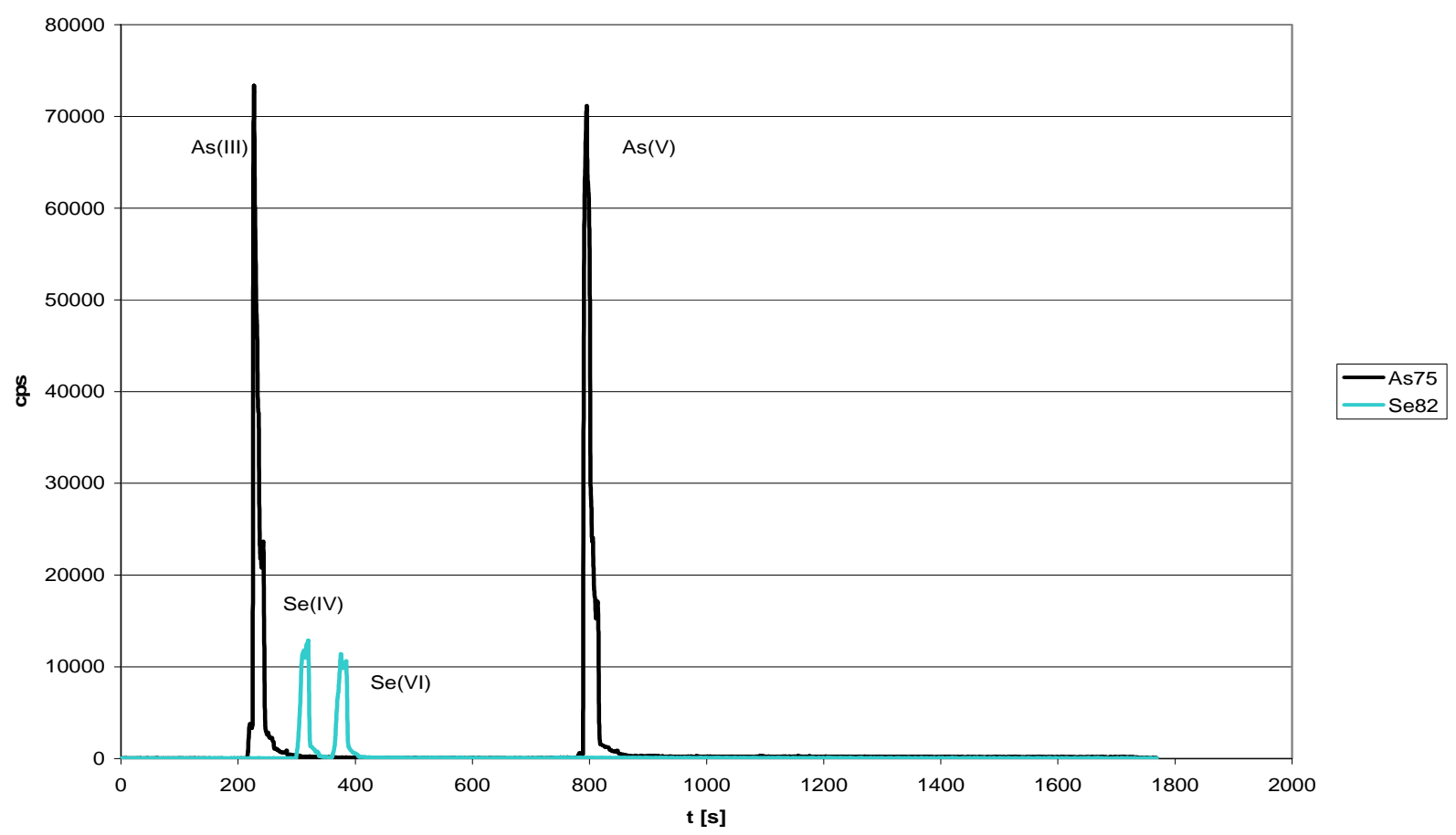

Figure 2-1

Chromatograph Showing 5 ppb each for As(III), As(V), Se(IV), and Se(VI)

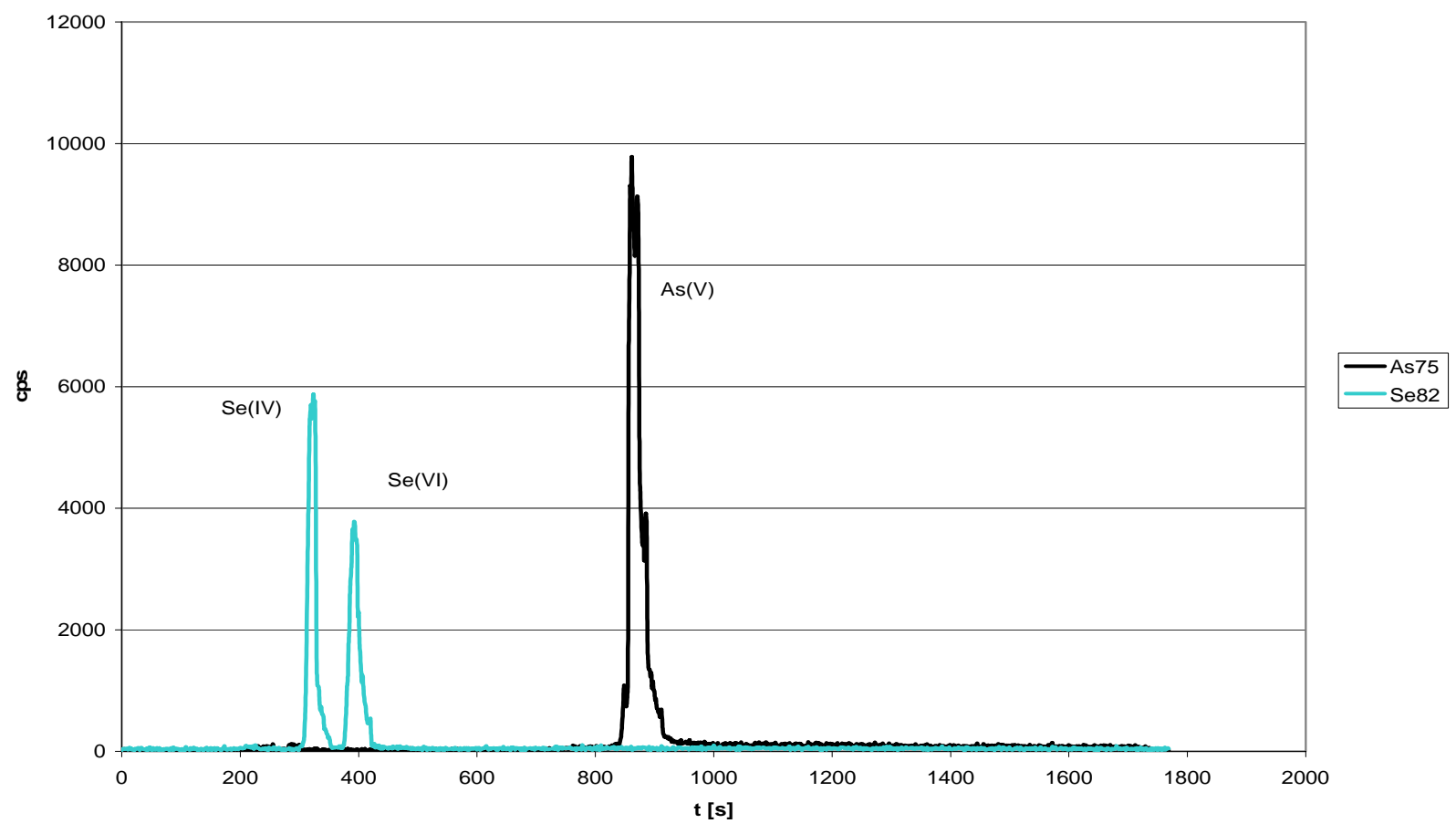

Figure 2-2

Chromatograph Showing Selenium and Arsenic Species for a Real Sample (10x dilution) 


\section{Chromium Speciation by lon-Chromatography Anion Self-Regenerating Suppressor DRC-ICP-MS (IC-ASRS-DRC-ICP-MS)}

$\mathrm{Cr}(\mathrm{III})$ and $\mathrm{Cr}(\mathrm{VI})$ were determined by IC-ASRS-DRC-ICP-MS using a Dionex ionchromatography system with ASRS coupled to a Perkin-Elmer DRC II in DRC mode. This analysis was performed separately from the $\mathrm{As}+\mathrm{Se}$ determination, because $\mathrm{Cr}$ (III) must first be derivatized off-line to (EDTA-Cr) ${ }^{-}$before it can be determined together with $\mathrm{Cr}$ (VI) by anionchromatography prior to ICP-MS detection (Gürleyük and Wallschläger, 2001) (Figures 2-3 and 2-4). Modifications from the method are listed in Table 2-3.

Table 2-3

Method Parameters for As+Se and Cr Speciation by IC-ASRS-DRC-ICP-MS

\begin{tabular}{|l|l|l|}
\hline & Arsenic + Selenium & Chromium \\
\hline Column & Dionex AS-16 4-mm + AG-16 4-mm & Dionex AS-16 4-mm + AG-16 4-mm \\
\hline Eluent & $\begin{array}{l}0-7 \mathrm{~min}: 20 \mathrm{mM} \mathrm{NaOH} \\
7 \rightarrow 17 \mathrm{~min} 20 \rightarrow 100 \mathrm{mM} \mathrm{NaOH} \\
17-25 \mathrm{~min} 100 \mathrm{mM} \mathrm{NaOH} \\
25-18 \mathrm{~min} 20 \mathrm{mM} \mathrm{NaOH}\end{array}$ & $20 \mathrm{mM} \mathrm{NaOH}$ \\
\hline $\begin{array}{l}\text { Injection } \\
\text { volume }\end{array}$ & $1 \mathrm{ml}$ & $1 \mathrm{ml}$ \\
\hline Flow rate & $1.2 \mathrm{ml} / \mathrm{min}$ & $1.5 \mathrm{ml} / \mathrm{min}$ \\
\hline Reaction gas & none & $\mathrm{NH}_{3}=0.3 \mathrm{ml} / \mathrm{min}$ \\
\hline Bandpass & none & $\mathrm{RPq}^{2} 0.3$ \\
\hline $\begin{array}{l}\text { Typical IDL } \\
\text { [ppb] }\end{array}$ & $\begin{array}{l}0.1 \mathrm{As}(\mathrm{III}), 0.4 \mathrm{As}(\mathrm{V}), 0.05 \mathrm{Se}(\mathrm{IV}), 0.05 \\
\text { Se(VI) }\end{array}$ & $0.01 \mathrm{Cr}(\mathrm{III}), 0.01 \mathrm{Cr}(\mathrm{VI})$ \\
\hline
\end{tabular}




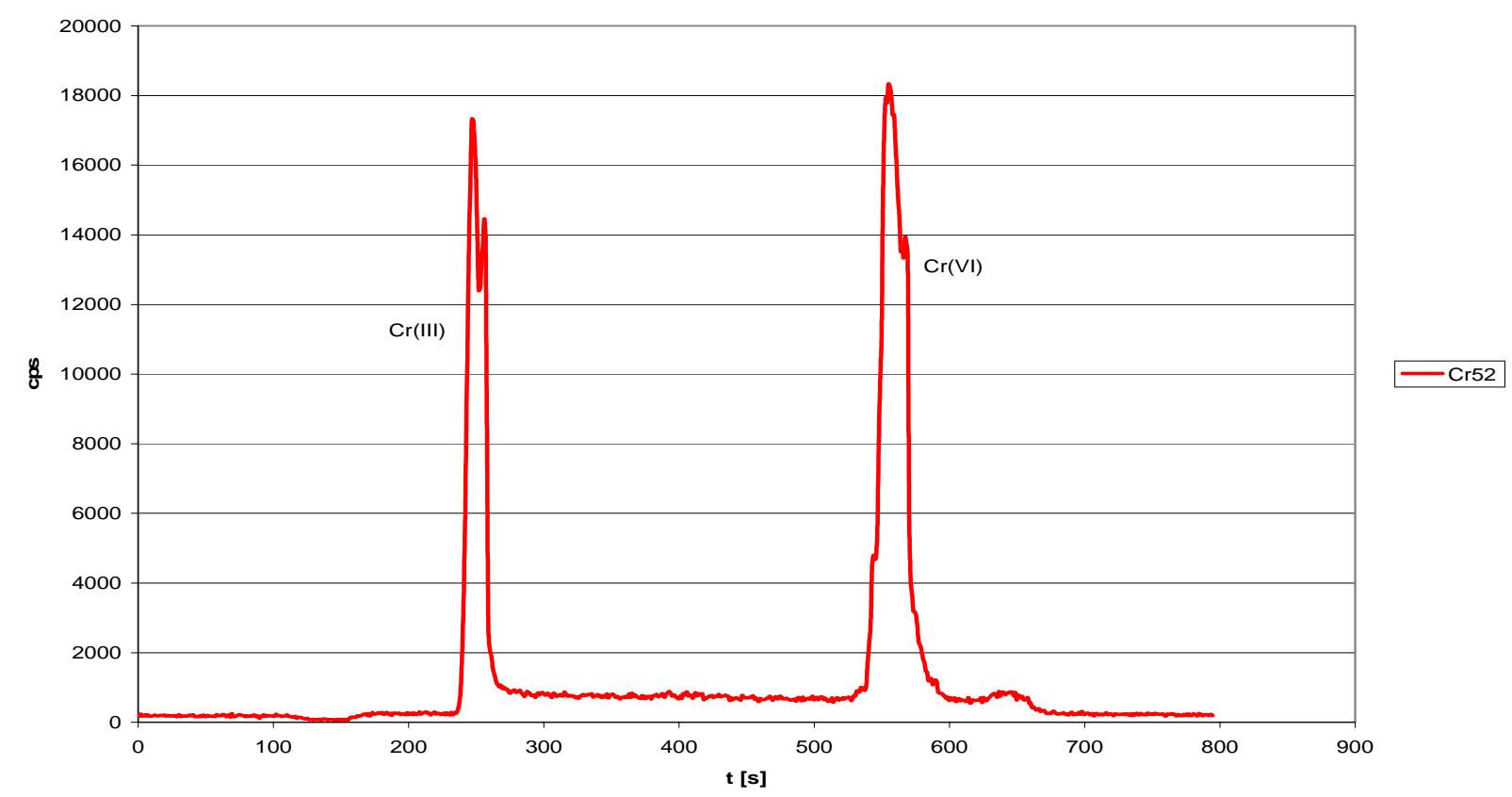

Figure 2-3

Chromatograph Showing $0.5 \mathrm{ppb}$ each for $\mathrm{Cr}(\mathrm{III})$ and $\mathrm{Cr}(\mathrm{VI})$

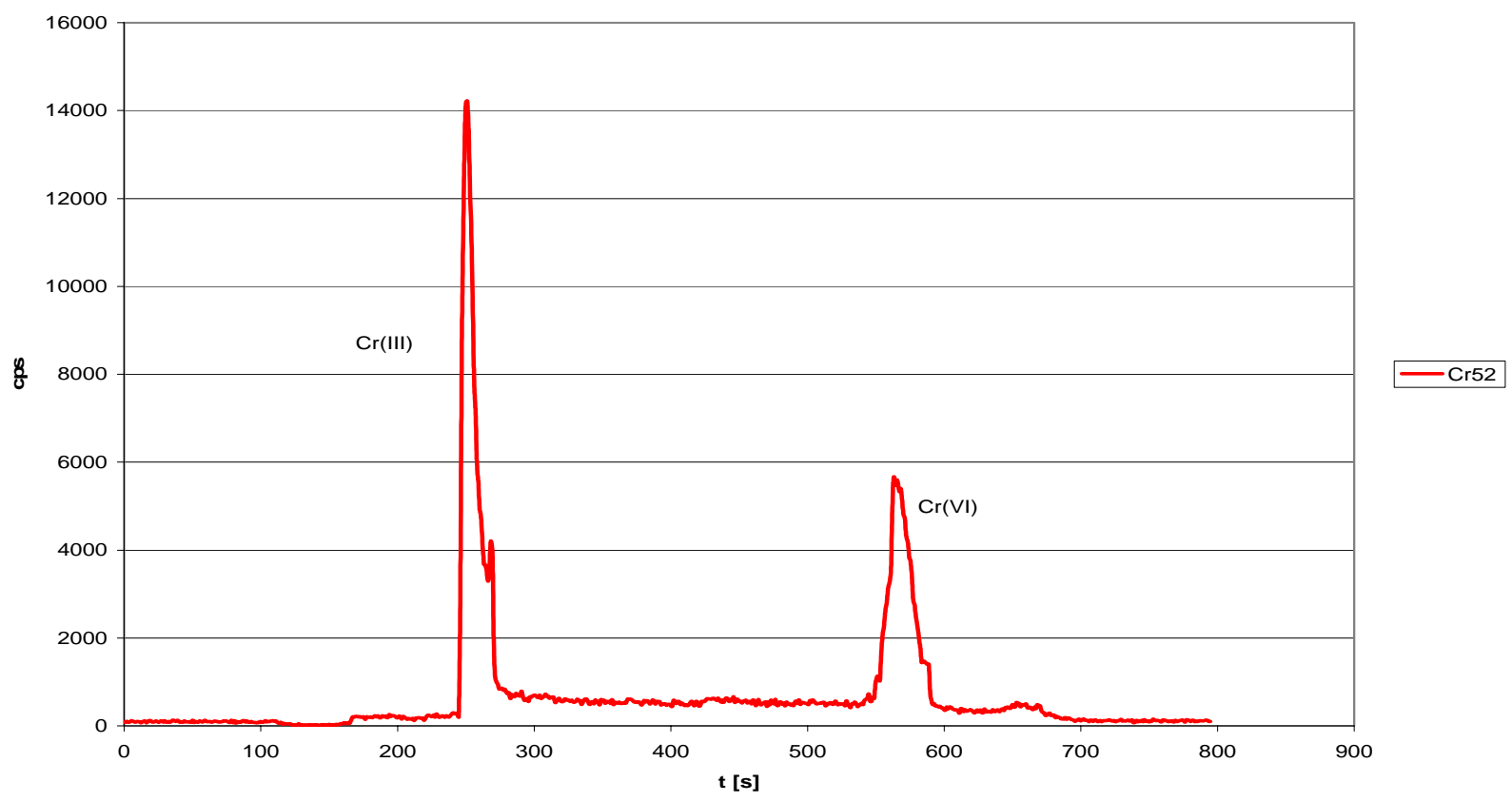

Figure 2-4

Chromatograph for Sample \#34 Analyzed at a 2x Dilution 


\section{Mercury Speciation Methods}

As previously described, DMM was purged from the collected water samples with an argon stream in the field, and collected on Carbotrap ${ }^{\mathrm{TM}}$ adsorbent tubes. These tubes were dried with an argon stream opposite to the adsorption direction, sealed, and kept cold and dark until analysis. DMM was thermally desorbed from the adsorbent trap and analyzed by gas chromatographyICP-MS (GC-ICP-MS) (similar to Lindberg et al., 2004).

Monomethyl mercury was determined by GC-ICP-MS after derivatization to methylethylmercury with sodium tetraethylborate. $\mathrm{MeHg}$ was isolated from filtered waters and particulate matter (yielding dissolved and particulate $\mathrm{MeHg}$ ) by steam distillation as methylmercury chloride $(\mathrm{MeHgCl})$, and determined using isotope dilution with isotopicallyenriched MeHg. Total mercury (THg) in filtered waters and filters with particulate matter (yielding dissolved and particulate mercury) was determined by cold vapor-ICP-MS (CV-ICPMS) also using isotope dilution. Samples for $\mathrm{THg}$ analysis were digested with $\mathrm{BrCl}$ and prereduced with $\mathrm{NH}_{2} \mathrm{OH} \cdot \mathrm{HCl}$ prior to the $\mathrm{CV}$-ICP-MS measurement (Hintelmann and Ogrinc, 2003).

\section{Ancillary Parameters}

Redox potential, $\mathrm{pH}$, conductivity, dissolved oxygen, and temperature were determined in the field on the filtered samples with a YSI multiprobe (for wells, this happened immediately after the low-flow conditions had stabilized; for all other types of water samples, this was done prior to collecting all other aliquots). Separate aliquots were used for these analyses and discarded afterwards.

Sodium, potassium, magnesium, and calcium were determined by cation-exchange chromatography with suppressed conductivity detection, and chloride and sulfate were determined by anion-exchange chromatography using the same detection principle, following standard methods. Total carbon (TC) and total inorganic carbon (TIC) were determined by flow injection-infrared spectrometry (Shimadzu Total Organic Carbon Analyzer) following standard methods, where TIC is liberated from the sample by addition of $\mathrm{HCl}$, while TC is liberated by oxygen combustion; total organic carbon (TOC) is then determined by difference TC-TIC, which may lead to imprecise results in samples with low TOC content. 


\section{SAMPLE SUMMARY}

\section{Sample Site Attributes}

The selected sample sites are concentrated in the eastern United States where coal-fired power plants predominate (Figure 3-1). The sites are nearly evenly split between landfills and impoundments (Table 3-1). Other characteristics of the sample sites include:

- Fly ash is managed at most sites; five sites manage FGD solids or FGD solids stabilized with or codisposed with fly ash, and two sites manage spray dryer ash.

- Seventeen sites received CCP from plants burning bituminous coal, 11 from plants burning subbituminous coal, six received CCP from a mixture of coals, and three received ash from lignite plants.

- Dry bottom pulverizers were the predominant boiler type for the source power plants.

- Electrostatic precipitators (ESPs) were the predominant particulate control device, and most ESPs were cold-side; in addition, four sites received CCP from fabric filters, one from a cyclone collection device, and one listed a wet ESP as the primary control device.

- Low-NOx burners were the primary NOx control. Several plants had recently added or were planning to add selective catalytic reduction (SCR) and selective non-catalytic reduction (SNCR) devices. At many plants, the NOx control devices varied by unit.

- Fourteen sites received CCP from units using flue gas conditioning to enhance precipitator performance. 


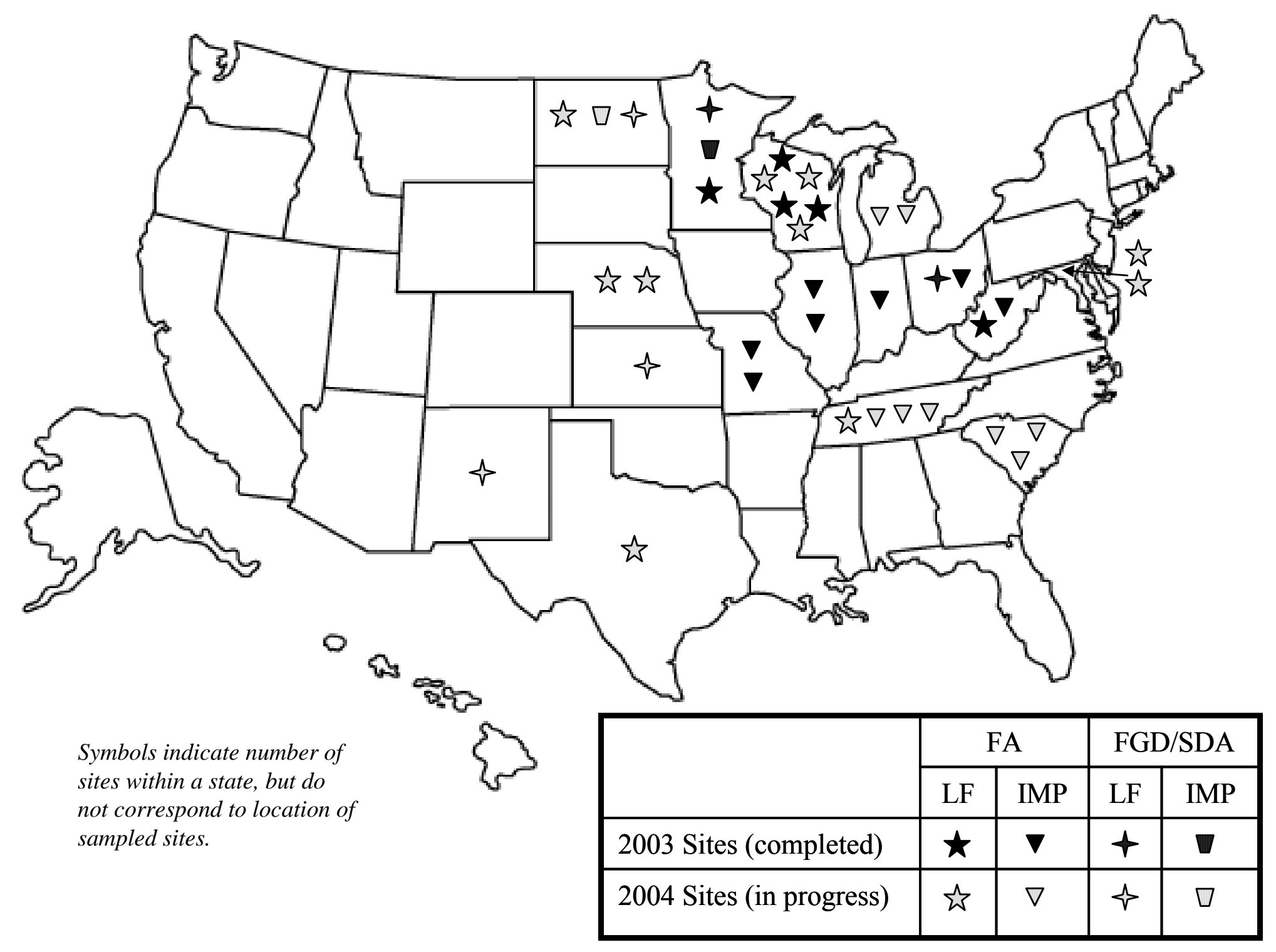

Figure 3-1

Sample Site Locations by State 
Table 3-1

Summary of Sampled Sites

\begin{tabular}{|c|c|c|c|c|c|c|c|c|c|c|}
\hline \multirow{2}{*}{$\begin{array}{l}\text { Site } \\
\text { Code }\end{array}$} & \multirow{2}{*}{$\begin{array}{l}\text { Sample } \\
\text { IDs }\end{array}$} & \multirow{2}{*}{$\begin{array}{l}\text { Management } \\
\text { Method }\end{array}$} & \multirow{2}{*}{$\begin{array}{l}\text { CCP } \\
\text { Managed }\end{array}$} & \multicolumn{2}{|c|}{ Source Coal } & \multirow[b]{2}{*}{ Boiler } & \multicolumn{3}{|c|}{ Source Plant } & \multirow[b]{2}{*}{$\begin{array}{l}\text { Flue Gas } \\
\text { Cond. }\end{array}$} \\
\hline & & & & Type & Region & & $\begin{array}{l}\text { Particulate } \\
\text { Coll. }\end{array}$ & FGD System & NOx Control & \\
\hline AK & 10,11 & Landfill & FA Class C & Subbit & $\begin{array}{l}\text { PRB }+5 \% \\
\text { pet coke }\end{array}$ & $\begin{array}{l}\text { Wet Bottom } \\
\text { Cyclone }\end{array}$ & $\begin{array}{l}\text { ESP - cold } \\
\text { side }\end{array}$ & No & $\begin{array}{l}\text { Overfired Air } \\
-2001\end{array}$ & No \\
\hline $\mathrm{AL}$ & 4,5 & Landfill & FA, BA & $\operatorname{mix}$ & $\begin{array}{l}\text { Western \& } \\
\text { S. Illinois }\end{array}$ & $\begin{array}{l}\text { Dry Bottom } \\
\text { Pulverizer ( } 3 \\
\text { plants, varies } \\
\text { by plant) }\end{array}$ & $\begin{array}{l}\text { ESP - cold } \\
\text { side ( } 2 \text { plants), } \\
\text { - hot side (1 } \\
\text { plant) }\end{array}$ & No & $\begin{array}{l}\text { Low NOx (1 } \\
\text { plant) }\end{array}$ & $\begin{array}{l}\text { Yes }(2 \\
\text { plants })\end{array}$ \\
\hline AN & 2004 & Impoundment & FA, BA & Bit & $\begin{array}{l}\text { West } \\
\text { Virginia }\end{array}$ & $\begin{array}{l}\text { Dry Bottom } \\
\text { Pulverizer- } \\
\text { Tangential }\end{array}$ & $\begin{array}{l}\text { ESP - cold } \\
\text { side }\end{array}$ & No & $\begin{array}{l}\text { Low NOx } \\
\text { Burner, } \\
\text { SNCR (U1) }\end{array}$ & $\begin{array}{l}\text { Yes (U } \\
3,4,5)\end{array}$ \\
\hline $\mathrm{BB} 1$ & 2004 & Landfill & $\mathrm{FA}, \mathrm{BA}$ & Bit & $\begin{array}{l}\text { Southern } \\
\text { Appalachian }\end{array}$ & $\begin{array}{l}\text { Dry Bottom } \\
\text { Pulverizer- } \\
\text { Opposed }\end{array}$ & $\begin{array}{l}\text { ESP - may be } \\
\text { a mix }\end{array}$ & No & $\begin{array}{l}\text { Low NOx } \\
\text { Burners, } \\
\text { Overfire Air, } \\
\text { SCR }\end{array}$ & No \\
\hline BB2 & 2004 & Landfill & FA, BA & Bit & $\begin{array}{l}\text { Southern } \\
\text { Appalachian }\end{array}$ & $\begin{array}{l}\text { Dry Bottom } \\
\text { Pulverizer- } \\
\text { Opposed }\end{array}$ & $\begin{array}{l}\text { ESP - may be } \\
\text { a mix }\end{array}$ & No & $\begin{array}{l}\text { Low NOx } \\
\text { Burners, } \\
\text { Overfire Air, } \\
\text { SCR }\end{array}$ & No \\
\hline BR1 & 2004 & Landfill & FA & Bit & $\begin{array}{l}\text { Kentucky } \\
\text { Low-Sulfur }\end{array}$ & $\begin{array}{l}\text { Dry Bottom } \\
\text { Pulverizer- } \\
\text { Tangential }\end{array}$ & $\begin{array}{l}\text { ESP - cold } \\
\text { side }\end{array}$ & No & $\begin{array}{l}\text { other - SCR } \\
\text { to be added. }\end{array}$ & No \\
\hline BR2 & 2004 & Impoundment & FA, BA & Bit & $\begin{array}{l}\text { Kentucky } \\
\text { Low-Sulfur }\end{array}$ & $\begin{array}{l}\text { Dry Bottom } \\
\text { Pulverizer- } \\
\text { Tangential }\end{array}$ & $\begin{array}{l}\text { ESP - cold } \\
\text { side }\end{array}$ & No & $\begin{array}{l}\text { other - SCR } \\
\text { to be added. }\end{array}$ & No \\
\hline $\mathrm{CC} 1$ & 2004 & Impoundment & FGD, BA & Lig & $\begin{array}{l}\text { North } \\
\text { Dakota }\end{array}$ & $\begin{array}{l}\text { Dry Bottom } \\
\text { Pulverizer- } \\
\text { Tangential } \\
\end{array}$ & $\begin{array}{l}\text { ESP - cold } \\
\text { side }\end{array}$ & $\begin{array}{l}\text { Wet Scrubber } \\
\text { - Spray Type } \\
\text { - Mag Lime }\end{array}$ & $\begin{array}{l}\text { Low NOx } \\
\text { Burner - OFA }\end{array}$ & No \\
\hline $\mathrm{CC} 2$ & 2004 & Landfill & $\begin{array}{l}\text { FGD, FA, } \\
\text { BA }\end{array}$ & Lig & $\begin{array}{l}\text { North } \\
\text { Dakota }\end{array}$ & $\begin{array}{l}\text { Dry Bottom } \\
\text { Pulverizer- } \\
\text { Tangential }\end{array}$ & $\begin{array}{l}\text { ESP - cold } \\
\text { side }\end{array}$ & $\begin{array}{l}\text { Wet Scrubber } \\
\text { - Spray Type } \\
\text { - Mag Lime }\end{array}$ & $\begin{array}{l}\text { Low NOx } \\
\text { Burner - OFA }\end{array}$ & No \\
\hline $\mathrm{CC} 3$ & 2004 & Landfill & FA & Lig & $\begin{array}{l}\text { North } \\
\text { Dakota }\end{array}$ & $\begin{array}{l}\text { Dry Bottom } \\
\text { Pulverizer- } \\
\text { Tangential }\end{array}$ & $\begin{array}{l}\text { ESP - cold } \\
\text { side }\end{array}$ & $\begin{array}{l}\text { Wet Scrubber } \\
\text { - Spray Type } \\
\text { - Mag Lime }\end{array}$ & $\begin{array}{l}\text { Low NOx } \\
\text { Burner - OFA }\end{array}$ & No \\
\hline
\end{tabular}




\begin{tabular}{|c|c|c|c|c|c|c|c|c|c|c|}
\hline \multirow{2}{*}{$\begin{array}{l}\text { Site } \\
\text { Code }\end{array}$} & \multirow{2}{*}{$\begin{array}{l}\text { Sample } \\
\text { IDs }\end{array}$} & \multirow{2}{*}{$\begin{array}{l}\text { Management } \\
\text { Method }\end{array}$} & \multirow{2}{*}{$\begin{array}{l}\text { CCP } \\
\text { Managed }\end{array}$} & \multicolumn{2}{|c|}{ Source Coal } & \multirow[b]{2}{*}{ Boiler } & \multicolumn{3}{|c|}{ Source Plant } & \multirow[b]{2}{*}{$\begin{array}{l}\text { Flue Gas } \\
\text { Cond. }\end{array}$} \\
\hline & & & & Type & Region & & $\begin{array}{l}\text { Particulate } \\
\text { Coll. }\end{array}$ & FGD System & NOx Control & \\
\hline $\mathrm{CL}$ & 2004 & Impoundment & FA, BA & Bit & Kentucky & $\begin{array}{l}\text { Dry Bottom } \\
\text { Pulverizer- } \\
\text { Tangential }\end{array}$ & $\begin{array}{l}\text { ESP - cold } \\
\text { side }\end{array}$ & No & SCR & No \\
\hline $\mathrm{CS}$ & 2004 & Landfill & FA, BA & Bit & $\begin{array}{l}\text { Southern } \\
\text { Illinois - } \\
\text { Rend Lake }\end{array}$ & $\begin{array}{l}\text { Pulverizer- } \\
\text { Wall }\end{array}$ & ESP & No & No & No \\
\hline CV1 & $\begin{array}{l}27,28, \\
29\end{array}$ & Impoundment & FA & Bit & $\begin{array}{l}\text { Northern } \\
\text { Appalachian }\end{array}$ & $\begin{array}{l}\text { Dry Bottom } \\
\text { Pulverizer- } \\
\text { Tangential / } \\
\text { Front, WB } \\
\text { Cyclone }\end{array}$ & $\begin{array}{l}\text { ESP - cold } \\
\text { side }\end{array}$ & $\begin{array}{l}\text { Wet Scrubber } \\
-\mathrm{Mg} \\
\text { enhanced } \\
\text { lime }\end{array}$ & $\begin{array}{l}\text { Low NOx } \\
\text { Burner }\end{array}$ & No \\
\hline CV2 & $\begin{array}{l}30,31, \\
32\end{array}$ & Landfill & FGD, FA & Bit & $\begin{array}{l}\text { Northern } \\
\text { Appalachian }\end{array}$ & $\begin{array}{l}\text { Dry Bottom } \\
\text { Pulverizer- } \\
\text { Tangential }\end{array}$ & $\begin{array}{l}\text { ESP - cold } \\
\text { side }\end{array}$ & $\begin{array}{l}\text { Wet Scrubber } \\
-\mathrm{Mg} \\
\text { enhanced } \\
\text { lime }\end{array}$ & $\begin{array}{l}\text { Low NOx } \\
\text { Burner }\end{array}$ & $\begin{array}{l}\text { Yes, last } \\
\text { couple } \\
\text { years }\end{array}$ \\
\hline $\mathrm{ES}$ & 2004 & Landfill & $\begin{array}{l}\text { FA, FGD, } \\
\text { BA }\end{array}$ & Subbit & $\begin{array}{l}\text { Western-Lee } \\
\text { Ranch Mine }\end{array}$ & $\begin{array}{l}\text { Dry Bottom } \\
\text { Pulverizer- } \\
\text { Tangential }\end{array}$ & $\begin{array}{l}\text { FF - reverse } \\
\text { air }\end{array}$ & $\begin{array}{l}\text { Wet Scrubber } \\
\text { - Spray Type } \\
\text { - Limestone }\end{array}$ & Excess Air & No \\
\hline HNE & $\begin{array}{l}17,19, \\
20\end{array}$ & Impoundment & FA, BA & Subbit & Western & $\begin{array}{l}\text { Dry Bottom } \\
\text { Pulverizer- } \\
\text { Tangential }\end{array}$ & $\begin{array}{l}\text { ESP - cold } \\
\text { side }\end{array}$ & No & $\begin{array}{l}\text { Overfire/Low } \\
\text { NOx Burner, } \\
4 / 03\end{array}$ & Yes \\
\hline HNW & $\begin{array}{l}18, \\
\text { Core1, } \\
\text { Core2 }\end{array}$ & Impoundment & FA, BA & Bit & Illinois & $\begin{array}{l}\text { Dry Bottom } \\
\text { Pulverizer- } \\
\text { Tangential }\end{array}$ & $\begin{array}{l}\text { ESP - cold } \\
\text { side }\end{array}$ & No & $\begin{array}{l}\text { Gas reburn } \\
\text { sorbent } \\
\text { injection for } 1 \\
\text { year }\end{array}$ & Yes \\
\hline $\mathrm{HO}$ & 2004 & Landfill & SDA & Subbit & PRB & $\begin{array}{l}\text { Dry Bottom } \\
\text { Pulverizer- } \\
\text { Opposed }\end{array}$ & $\begin{array}{l}\text { FF \& Spray } \\
\text { Dryer }\end{array}$ & $\begin{array}{l}\text { Dry Injection } \\
\text { - spray dryer }\end{array}$ & $\begin{array}{l}\text { Low NOx } \\
\text { Burner }\end{array}$ & not listed \\
\hline JA1 & $\begin{array}{l}21,22, \\
23,26\end{array}$ & Impoundment & FA & Bit & $\begin{array}{l}\text { Central } \\
\text { Appalachian }\end{array}$ & $\begin{array}{l}\text { Dry Bottom } \\
\text { Pulverizer- } \\
\text { Opposed }\end{array}$ & $\begin{array}{l}\text { ESP - cold } \\
\text { side }\end{array}$ & No & $\begin{array}{l}\text { Low NOx } \\
\text { Burner \& } \\
\text { SCR since } 02\end{array}$ & Yes \\
\hline JA2 & 24,25 & Landfill & FA & Bit & $\begin{array}{l}\text { Central } \\
\text { Appalachian }\end{array}$ & $\begin{array}{l}\text { Dry Bottom } \\
\text { Pulverizer- } \\
\text { Opposed }\end{array}$ & $\begin{array}{l}\text { ESP - cold } \\
\text { side }\end{array}$ & No & $\begin{array}{l}\text { Low NOx } \\
\text { Burner }\end{array}$ & No \\
\hline JS & 2004 & Impoundment & FA, BA & Bit & SW Virginia & $\begin{array}{l}\text { Dry Bottom } \\
\text { Pulverizer- } \\
\text { Tangential }\end{array}$ & ESP & No & & not listed \\
\hline
\end{tabular}




\begin{tabular}{|c|c|c|c|c|c|c|c|c|c|c|}
\hline \multirow{2}{*}{$\begin{array}{l}\text { Site } \\
\text { Code }\end{array}$} & \multirow{2}{*}{$\begin{array}{l}\text { Sample } \\
\text { IDs }\end{array}$} & \multirow{2}{*}{$\begin{array}{l}\text { Management } \\
\text { Method }\end{array}$} & \multirow{2}{*}{$\begin{array}{l}\text { CCP } \\
\text { Managed }\end{array}$} & \multicolumn{2}{|c|}{ Source Coal } & \multicolumn{5}{|c|}{ Source Plant } \\
\hline & & & & Type & Region & Boiler & $\begin{array}{l}\text { Particulate } \\
\text { Coll. }\end{array}$ & FGD System & NOx Control & $\begin{array}{l}\text { Flue Gas } \\
\text { Cond. }\end{array}$ \\
\hline KI & 2004 & Impoundment & $\begin{array}{l}\text { FA, some } \\
\text { BA }\end{array}$ & Bit & $\begin{array}{l}\text { E Tennessee } \\
\& \text { Kentucky, } \\
\text { low sulfur }\end{array}$ & $\begin{array}{l}\text { Dry Bottom } \\
\text { Pulverizer- } \\
\text { Tangential }\end{array}$ & Cyclone & No & $\begin{array}{l}\text { Low NOx } \\
\text { Burners (4 } \\
\text { units) } \\
\end{array}$ & not listed \\
\hline KW1 & 2004 & Impoundment & FA, BA & $\operatorname{mix}$ & $\begin{array}{l}\text { Formerly all } \\
\text { Bit, } 80 \% \\
\text { Subbit } 20 \% \\
\text { Bit since } \\
2002\end{array}$ & $\begin{array}{l}\text { Dry Bottom } \\
\text { Pulverizer- } \\
\text { Tangential } \\
\text { (U1),Front } \\
\text { (U2) }\end{array}$ & $\begin{array}{l}\text { ESP - cold } \\
\text { side }\end{array}$ & No & $\begin{array}{l}\text { Low NOx } \\
\text { Burner (U2) }\end{array}$ & Yes \\
\hline KW2 & 2004 & Impoundment & FA, BA & $\operatorname{mix}$ & $\begin{array}{l}\text { Formerly all } \\
\text { Bit, } 80 \% \\
\text { Subbit } 20 \% \\
\text { Bit since } \\
2002\end{array}$ & $\begin{array}{l}\text { Dry Bottom } \\
\text { Pulverizer- } \\
\text { Tangential }\end{array}$ & $\begin{array}{l}\text { ESP - cold } \\
\text { side }\end{array}$ & No & & Yes \\
\hline $\mathrm{L}$ & 2004 & Impoundment & $\mathrm{FA}, \mathrm{BA}$ & Bit & Eastern & $\begin{array}{l}\text { Dry Bottom } \\
\text { Pulverizer- } \\
\text { Tangential }\end{array}$ & ESP - hot side & No & $\begin{array}{l}\text { Overfire Air } \\
\text { \& Low NOx } \\
\text { Burner }\end{array}$ & No \\
\hline $\mathrm{NC}$ & 2004 & Landfill & FA, BA & Subbit & PRB & $\begin{array}{l}\text { Dry Bottom } \\
\text { Pulverizer- } \\
\text { Opposed }\end{array}$ & $\begin{array}{l}\text { ESP - cold } \\
\text { side }\end{array}$ & No & Overfire Air & No \\
\hline NO & 2004 & Landfill & FA, BA & Subbit & PRB & $\begin{array}{l}\text { Dry Bottom } \\
\text { Pulverizer- } \\
\text { Front \& } \\
\text { Tangential }\end{array}$ & $\begin{array}{l}\text { ESP - cold } \\
\text { side }\end{array}$ & No & $\begin{array}{l}\text { Low NOx } \\
\text { Burner (3 } \\
\text { units) }\end{array}$ & $\begin{array}{l}\text { Yes (U } \\
1,2,3,4)\end{array}$ \\
\hline $\mathrm{OC}$ & 1 & Landfill & FA, BA & $\operatorname{mix}$ & & $\begin{array}{l}\text { Dry Bottom } \\
\text { Pulverizer- } \\
\text { Front \& } \\
\text { Tangential }\end{array}$ & $\begin{array}{l}\text { ESP - cold } \\
\text { side }\end{array}$ & No & $\begin{array}{l}\text { Low NOx } \\
\text { Burner (3 } \\
\text { units) }\end{array}$ & No \\
\hline PU & 2004 & Landfill & FA & Subbit & & $\begin{array}{l}\text { Dry-Bottom } \\
\text { Pulverizer- } \\
\text { Rear }\end{array}$ & $\begin{array}{l}\text { ESP - cold } \\
\text { side }\end{array}$ & No & $\begin{array}{l}\text { Low NOx } \\
\text { burner ( } 2 \\
\text { units) } \\
\end{array}$ & Yes \\
\hline $\mathrm{SC} 1$ & 6 & Landfill & SDA & Subbit & PRB & $\begin{array}{l}\text { Dry Bottom } \\
\text { Pulverizer- } \\
\text { Opposed \& } \\
\text { Tangential } \\
\end{array}$ & $\begin{array}{l}\text { FF \& Spray } \\
\text { Dryer }\end{array}$ & $\begin{array}{l}\text { Dry Injection } \\
\text { - lime spray } \\
\text { dryer }\end{array}$ & $\begin{array}{l}\text { Overfire Air } \\
\text { (U1), Low- } \\
\text { NOx Burner } \\
(\mathrm{U} 2 \& 3)\end{array}$ & not listed \\
\hline
\end{tabular}




\begin{tabular}{|c|c|c|c|c|c|c|c|c|c|c|}
\hline \multirow{2}{*}{$\begin{array}{l}\text { Site } \\
\text { Code }\end{array}$} & \multirow{2}{*}{$\begin{array}{l}\text { Sample } \\
\text { IDs }\end{array}$} & \multirow{2}{*}{$\begin{array}{l}\text { Management } \\
\text { Method }\end{array}$} & \multirow{2}{*}{$\begin{array}{l}\text { CCP } \\
\text { Managed }\end{array}$} & \multicolumn{2}{|c|}{ Source Coal } & \multicolumn{5}{|c|}{ Source Plant } \\
\hline & & & & Type & Region & Boiler & $\begin{array}{l}\text { Particulate } \\
\text { Coll. }\end{array}$ & FGD System & NOx Control & $\begin{array}{l}\text { Flue Gas } \\
\text { Cond. }\end{array}$ \\
\hline $\mathrm{SC} 2$ & $7,8,9$ & Impoundment & FGD & Subbit & PRB & $\begin{array}{l}\text { Dry Bottom } \\
\text { Pulverizer- } \\
\text { Opposed \& } \\
\text { Tangential }\end{array}$ & Wet ESP & $\begin{array}{l}\text { Wet Scrubber } \\
\text { - Dual Alkali }\end{array}$ & $\begin{array}{l}\text { Overfire Air } \\
\text { (U1), Low- } \\
\text { NOx Burner } \\
\text { (U2\&3) }\end{array}$ & not listed \\
\hline SX1 & 15,16 & Impoundment & FA, BA & $\operatorname{mix}$ & $\begin{array}{l}\text { PRB \& } \\
\text { Illinois }\end{array}$ & $\begin{array}{l}\text { Wet Bottom } \\
\text { Cyclone }\end{array}$ & $\begin{array}{l}\text { ESP - cold } \\
\text { side }\end{array}$ & No & Overfire Air & Yes \\
\hline SX2 & Core3 & Impoundment & FA & $\operatorname{mix}$ & $\begin{array}{l}\text { PRB \& } \\
\text { Illinois }\end{array}$ & $\begin{array}{l}\text { Wet Bottom } \\
\text { Cyclone }\end{array}$ & $\begin{array}{l}\text { ESP - cold } \\
\text { side }\end{array}$ & No & Overfire Air & Yes \\
\hline SY & 2004 & Landfill & FA & Bit & & $\begin{array}{l}\text { Dry Bottom } \\
\text { Pulverizer- } \\
\text { Front }\end{array}$ & FF - pulse & No & $\begin{array}{l}\text { Low NOx } \\
\text { Burner }\end{array}$ & not listed \\
\hline UV & $\begin{array}{l}12,13 \\
14\end{array}$ & $\begin{array}{l}\text { Landfill } \\
\text { (sluiced ash } \\
\text { from an } \\
\text { impoundment) }\end{array}$ & $\begin{array}{l}\text { FA } \\
\text { (sluiced) }\end{array}$ & Bit & Illinois & $\begin{array}{l}\text { Dry Bottom } \\
\text { Pulverizer- } \\
\text { Front \& } \\
\text { Tangential }\end{array}$ & $\begin{array}{l}\text { ESP - cold } \\
\text { side }\end{array}$ & No & $\begin{array}{l}\text { Low NOx } \\
\text { Burner (U3) }\end{array}$ & $\begin{array}{l}\text { Yes (U } \\
2,3,4,6)\end{array}$ \\
\hline WL & 2004 & Landfill & FA & Subbit & PRB & $\begin{array}{l}\text { Dry Bottom } \\
\text { Pulverizer- } \\
\text { Opposed }\end{array}$ & ESP - hot side & No & $\begin{array}{l}\text { Low NOx } \\
\text { Burner }\end{array}$ & No \\
\hline WS & 2,3 & Landfill & FA & Subbit & PRB & $\begin{array}{l}\text { Dry Bottom } \\
\text { Pulverizer- } \\
\text { Tangential \& } \\
\text { Front }\end{array}$ & $\begin{array}{l}\text { ESP - cold } \\
(\mathrm{U} .1-2),- \text { hot } \\
(\mathrm{U} .3), \mathrm{FF}-\mathrm{U} .3 \\
(2001)\end{array}$ & No & $\begin{array}{l}\text { Low NOx } \\
\text { Burner (U3) }\end{array}$ & $\begin{array}{l}\text { Yes (U } \\
1,2)\end{array}$ \\
\hline
\end{tabular}


As of the end of 2003, 35 leachate samples were collected at 14 sites (Table 3-2), and an additional 68 samples were scheduled for the remaining 23 sites. Low-level mercury samples were collected, or were scheduled to be collected, at 13 sites. The 2003 sample breakdown is as follows:

- 16 landfill samples:

- 8 leachate collection system samples;

- 3 lysimeter samples;

- 5 leachate well samples.

- 19 impoundment samples:

- 4 ash/water interface samples;

- 4 drive-point piezometer samples;

- 3 leachate well samples;

- 3 samples from pond outfalls;

- 1 leachate seep;

- 1 sample of incoming sluice water from the sluice line;

- 3 porewater samples from ash cores.

- 28 samples were from fly ash or fly ash mixed with bottom ash, 6 samples were from FGD solids or FGD solids stabilized with fly ash, and 1 sample was from spray dryer ash.

- 18 samples of CCP derived from bituminous coal, 11 of CCP derived from subbituminous coal, and 6 derived from mixed coals.

- 30 samples from dry-bottom pulverizer boilers, 5 from wet-bottom cyclone boilers. 
Table 3-2

2003 Sample Summary

\begin{tabular}{|c|c|c|c|c|c|c|}
\hline Site & \begin{tabular}{|c|} 
Sample \\
ID
\end{tabular} & \begin{tabular}{|l|} 
CCP \\
Sampled $^{1}$ \\
\end{tabular} & Source & Sampling Point & Method & \begin{tabular}{|l|} 
Hg \\
Sample?
\end{tabular} \\
\hline $\mathrm{AK}$ & \begin{tabular}{|l|}
11 \\
\end{tabular} & FA, BA & Landfill & Lysimeter & Waterra Pump ${ }^{2}$ & No \\
\hline $\mathrm{AK}$ & 10 & FA, BA & Landfill & Leachate Collection System & Bailer $^{2}$ & No \\
\hline $\mathrm{AL}$ & 4 & FA, BA & Landfill & Leachate Collection System & Peristaltic Pump & Yes \\
\hline $\mathrm{AL}$ & 5 & FA, BA & Landfill & Leachate Well & Waterra Pump ${ }^{2}$ & Yes \\
\hline CV1 & 27 & FGD & Landfill & Leachate Collection System & Dip Sampler $^{2}$ & Yes \\
\hline CV1 & 28 & FGD & Landfill & Leachate Collection System & Dip Sampler $^{2}$ & Yes \\
\hline CV1 & 29 & FGD & Landfill & Leachate Collection System & Dip Sampler $^{2}$ & Yes \\
\hline CV2 & 30 & FA, BA & Impoundment & Outfall & Peristaltic Pump & Yes \\
\hline CV2 & 31 & FA & Impoundment & Drive Point Piezometer & Peristaltic Pump & Yes \\
\hline CV2 & 32 & FA & Impoundment & Seep & Dip Sampler ${ }^{2}$ & Yes \\
\hline HNE & 20 & FA, BA & Impoundment & Outfall & Peristaltic Pump & No \\
\hline HNE & 17 & FA, BA & Impoundment & Ash/Water Interface & Peristaltic Pump & No \\
\hline HNE & 19 & FA & Impoundment & Sluice Line & Dip Sampler $^{2}$ & No \\
\hline HNW & Core1 & FA, BA & Impoundment & Soil Boring & Core Extract & No \\
\hline HNW & Core 2 & FA, BA & Impoundment & Soil Boring & Core Extract & No \\
\hline HNW & 18 & FA, BA & Impoundment & Leachate Well & Peristaltic Pump & No \\
\hline JA1 & 21 & FA & Impoundment & Drive Point Piezometer & Peristaltic Pump & Yes \\
\hline JA1 & 23 & FA & Impoundment & Drive Point Piezometer & Peristaltic Pump & Yes \\
\hline JA1 & 22 & FA & Impoundment & Ash/Water Interface & Peristaltic Pump & Yes \\
\hline JA1 & 26 & FA & Impoundment & Outfall & Dip Sampler ${ }^{2}$ & Yes \\
\hline JA2 & 24 & FA & Landfill & Leachate Collection System & Dip Sampler $^{2}$ & No \\
\hline JA2 & 25 & FA & Landfill & Leachate Collection System & Dip Sampler $^{2}$ & No \\
\hline $\mathrm{OC}$ & 1 & FA, BA & Landfill & Leachate Well & Waterra Pump $^{2}$ & Yes \\
\hline $\mathrm{SC} 1$ & 6 & SDA & Landfill & Leachate Collection System & Peristaltic Pump & Yes \\
\hline $\mathrm{SC} 2$ & 7 & FGD & Impoundment & Leachate Well & Bladder Pump & Yes \\
\hline $\mathrm{SC} 2$ & 8 & FGD & Impoundment & Leachate Well & Bladder Pump & Yes \\
\hline $\mathrm{SC} 2$ & 9 & FGD & Impoundment & Ash/Water Interface & Peristaltic Pump & Yes \\
\hline SX1 & 16 & FA, BA & Impoundment & Drive Point Piezometer & Peristaltic Pump & No \\
\hline SX1 & 15 & FA, BA & Impoundment & Ash/Water Interface & Peristaltic Pump & No \\
\hline $\mathrm{SX} 2$ & Core3 & FA & Impoundment & Soil Boring & Core Extract & No \\
\hline UV & 13 & FA, BA & Landfill & Leachate Well & Peristaltic Pump & No \\
\hline UV & 12 & FA, BA & Landfill & Leachate Well & Waterra Pump ${ }^{2}$ & No \\
\hline UV & 14 & FA, BA & Landfill & Leachate Well & Peristaltic Pump & No \\
\hline WS & 2 & FA & Landfill & Lysimeter & Bladder Pump & Yes \\
\hline WS & 3 & FA & Landfill & Lysimeter & Bladder Pump & Yes \\
\hline
\end{tabular}

1. FA — fly ash, BA — bottom ash, FGD_FGD solids, SDA—-spray dryer ash

2. Sample was discharged to a flask; then extracted from the flask through the filter and to a sample bottle using a peristaltic pump. 


\section{4 \\ 2003 RESULTS}

\section{Summary of All Data}

Analytical data were entered in a database and reviewed for outliers; anomalous values were checked and corrected, if appropriate, by the Trent University laboratory. Carbonate and bicarbonate concentrations were calculated from total inorganic carbon (TIC) and $\mathrm{pH}$ based on the Henderson Hasselbach equation:

$$
\mathrm{pH}=\mathrm{pKa}+\log \left[\mathrm{CO}_{3}\right] /\left[\mathrm{HCO}_{3}\right], \text { where } \mathrm{pKa}=10.33
$$

All of the data for sites sampled in 2003 are statistically summarized in Table 4-1.

\section{Major Constituents}

Major constituent concentrations were converted to milliequivalents and plotted on ternary plots (Figure 4-1), which show the relative percentage of each constituent. The ternary plots show several distinct groupings of samples:

- Cation chemistry of most samples is dominated by calcium and/or sodium. Only sample 9 had a relatively high percentage of magnesium. Sample 9 was sampled at the ash/water interface of an FGD pond, and is from the only plant that listed a wet ESP and dual alkali wet scrubber as emission control devices. However, two leachate well samples from the same site (samples 7 and 8) had relatively low percentages of magnesium. Sample 9 had relatively high absolute concentrations of several other elements, and the concentrations of sulfate, magnesium, selenium, and mercury in this sample were higher than any other 2003 samples.

- Samples 27, 28, and 29 are fly ash samples, and the absolute concentrations of potassium $(>400 \mathrm{mg} / \mathrm{L})$ in these samples were higher than in any other samples. Magnesium concentrations were low in these samples, and in the FGD solids leachate samples from this plant (samples 30, 31, and 32), even though the FGD system at this plant used magnesium-enhanced lime as the FGD sorbent.

- Samples 1, 2, 3, 4, 7, 10, and 16 had relatively high percentages of sodium and potassium. The only similarity between these samples is that they are from plants that burn subbituminous or a mixture of subbituminous and bituminous coal. However, several samples from plants burning subbituminous coal did not fall into this grouping.

- Samples 6, 12, 13, 14, 15, 18, 30, and 31 had relatively high percentages of calcium. All except sample 6 were from plants burning bituminous or a mixture of bituminous and subbituminous coals. Sample 6 is from the only sampled plant with a spray dryer system.

- Anion chemistry for most samples is dominated by sulfate.

- Samples 27, 28, and 29 had a significant percentage of chloride, and the highest absolute concentrations of chloride ( $>900 \mathrm{mg} / \mathrm{L})$ in the 2003 samples. These samples are from a landfill that received FGD solids stabilized with fly ash derived from bituminous coal and with $2 \%$ to $3 \%$ lime. 
- Samples 17, 18, 19, and 20 are from different sites associated with the same power plant. Sample 18, which has a relatively high percentage of carbonates, is from an inactive site, and the plant had a considerably different configuration when that site was active. The relatively high percentage of chloride and carbonates in these samples may reflect their relatively low absolute sulfate concentrations $(<400 \mathrm{mg} / \mathrm{L})$.

- Sample 11 is dominated by carbonates, and has relatively low absolute concentrations of boron $(0.26 \mathrm{mg} / \mathrm{L})$ and sulfate $(93 \mathrm{mg} / \mathrm{L})$. This sample was collected from a lysimeter beneath the liner of a landfill. At the time of sample collection, it was thought that this lysimeter was above the water table, and any liquid in the lysimeter would be leachate. However, sample 10, which was collected from the leachate collection system at the same site, has higher absolute boron $(10.7 \mathrm{mg} / \mathrm{L})$ and sulfate $(3,830 \mathrm{mg} / \mathrm{L})$ concentrations, and distinctly different major constituent chemistry ratios. These differences suggest that sample 11 is not representative of CCP leachate; therefore, this sample is not included in the discussions that follow.

\section{Minor and Trace Elements}

Boron had the highest maximum, mean, and median concentration of the minor and trace elements (Table 4-1). Other minor and trace elements with median concentrations greater than $100 \mu \mathrm{g} / \mathrm{L}$ were aluminum, silica, strontium, and molybdenum; although the aluminum result is a function of the detection limit $(150 \mu \mathrm{g} / \mathrm{L})$. Elements with median concentrations less than $1 \mu \mathrm{g} / \mathrm{L}$ included chromium, lead, mercury, silver, and thallium. The maximum concentrations of beryllium, silver, and mercury were lower than $5 \mu \mathrm{g} / \mathrm{L}$.

Total arsenic concentrations ranged from 3 to $238 \mu \mathrm{g} / \mathrm{L}$, with a median of $24 \mu \mathrm{g} / \mathrm{L}$. Five samples, from three different sites, had an arsenic concentration greater than $100 \mu \mathrm{g} / \mathrm{L}$. In all five cases, the leachate was from sluiced fly ash $^{3}$ that was a by-product of bituminous coal. Conversely, five samples, from three different sites, had arsenic concentration lower than $10 \mu \mathrm{g} / \mathrm{L}$. There was no correlation between low arsenic concentration and management method or coal type.

Total selenium concentration exhibited a much larger range than arsenic, from 0.3 to $2,360 \mu \mathrm{g} / \mathrm{L}$, although the median selenium concentration of $15 \mu \mathrm{g} / \mathrm{L}$ was lower than for arsenic. Three samples from two sites had concentrations greater than $1,000 \mu \mathrm{g} / \mathrm{L}$, and five samples from four additional sites had concentrations greater than $100 \mu \mathrm{g} / \mathrm{L}$. These samples represented both FGD solids and fly ash leachate, from landfills and impoundments. The source coal for six of these eight samples was subbituminous, one was a mixture of bituminous and subbituminous, and only one was derived from bituminous coal. Fourteen samples had a selenium concentration lower than $10 \mu \mathrm{g} / \mathrm{L}$. These fourteen samples included all five of the arsenic samples with concentration lower than $10 \mu \mathrm{g} / \mathrm{L}$, and three of the five arsenic samples with concentration greater than $100 \mu \mathrm{g} / \mathrm{L}$. Again, there was no correlation between low selenium concentration and management method or coal type.

\footnotetext{
${ }^{3}$ Two of these samples are from a site characterized as a landfill; however, the fly ash in the landfill was excavated from an impoundment.
} 
Table 4-1

Statistical Summary of 2003 Samples

\begin{tabular}{|c|c|c|c|c|c|c|c|c|}
\hline Parameter & Unit & Count $^{1}$ & Minimum & Mean & Median & Maximum & Extreme $^{2}$ & $\%$ BDL \\
\hline \multicolumn{9}{|l|}{ Major Constituents } \\
\hline Bicarbonate (calc) & $\mathrm{mg} / \mathrm{L}$ & 31 & 1.0 & 105 & 60 & 584 & 18 & $0 \%$ \\
\hline Calcium & $\mathrm{mg} / \mathrm{L}$ & 31 & 9.1 & 299 & 231 & 730 & 29 & $0 \%$ \\
\hline Carbonate (calc) & $\mathrm{mg} / \mathrm{L}$ & 31 & $<0.1$ & 10 & 0.69 & 152 & 3 & $23 \%$ \\
\hline Chloride & $\mathrm{mg} / \mathrm{L}$ & 31 & 6.5 & 181 & 33 & 1,260 & 28 & $0 \%$ \\
\hline Magnesium & $\mathrm{mg} / \mathrm{L}$ & 31 & 0.53 & 97 & 23 & 1,990 & 9 & $0 \%$ \\
\hline Potassium & $\mathrm{mg} / \mathrm{L}$ & 31 & 0.95 & 96 & 24 & 581 & 28 & $0 \%$ \\
\hline Sodium & $\mathrm{mg} / \mathrm{L}$ & 31 & 17 & 471 & 79 & 3,410 & 2 & $0 \%$ \\
\hline Sulfate & $\mathrm{mg} / \mathrm{L}$ & 31 & 91 & 1,785 & 1,370 & 10,400 & 9 & $0 \%$ \\
\hline Carbon, total inorganic & $\mathrm{mg} / \mathrm{L}$ & 31 & 0.95 & 23 & 12 & 115 & 18 & $0 \%$ \\
\hline Carbon, total organic & $\mathrm{mg} / \mathrm{L}$ & 27 & 0.51 & 11.8 & 6.2 & 55 & 2 & $0 \%$ \\
\hline \multicolumn{9}{|l|}{ Minor and Trace Elements } \\
\hline Aluminum & $\mu \mathrm{g} / \mathrm{L}$ & 34 & $<150$ & 2,316 & $<150$ & 36,400 & 16 & $56 \%$ \\
\hline Antimony & $\mu \mathrm{g} / \mathrm{L}$ & 34 & $<0.25$ & 6.8 & 1.2 & 74 & 23 & $9 \%$ \\
\hline Arsenic (III) & $\mu \mathrm{g} / \mathrm{L}$ & 27 & $<0.25$ & 5.5 & $<2.5$ & 39 & 12 & $52 \%$ \\
\hline Arsenic (total) & $\mu \mathrm{g} / \mathrm{L}$ & 34 & 3.0 & 54 & 24 & 238 & 12 & $0 \%$ \\
\hline Arsenic (V) & $\mu \mathrm{g} / \mathrm{L}$ & 27 & $<0.1$ & 1.6 & $<0.2$ & 13 & 2 & $63 \%$ \\
\hline Barium & $\mu \mathrm{g} / \mathrm{L}$ & 34 & 27 & 99 & 68 & 298 & 15 & $0 \%$ \\
\hline Beryllium & $\mu \mathrm{g} / \mathrm{L}$ & 34 & 0.1 & 1.4 & 1.5 & 1.9 & 16 & $9 \%$ \\
\hline Boron & $\mu \mathrm{g} / \mathrm{L}$ & 34 & 456 & 20,293 & 8,855 & 102,000 & 12 & $0 \%$ \\
\hline Cadmium & $\mu \mathrm{g} / \mathrm{L}$ & 34 & 0.17 & 8.6 & 1.7 & 75 & 16 & $0 \%$ \\
\hline Chromium (total) & $\mu \mathrm{g} / \mathrm{L}$ & 34 & $<0.45$ & 184 & 0.51 & 3,150 & 2 & $47 \%$ \\
\hline Chromium (VI) & $\mu \mathrm{g} / \mathrm{L}$ & 27 & $<0.05$ & 221 & 0.90 & 3,220 & 2 & $33 \%$ \\
\hline Cobalt & $\mu \mathrm{g} / \mathrm{L}$ & 34 & $<0.02$ & 14 & 8.9 & 116 & 2 & $3 \%$ \\
\hline Copper & $\mu \mathrm{g} / \mathrm{L}$ & 34 & 1.6 & 31 & 15 & 401 & 2 & $0 \%$ \\
\hline Iron & $\mu \mathrm{g} / \mathrm{L}$ & 34 & 2.0 & 440 & 16 & 9,600 & 13 & $3 \%$ \\
\hline Lead & $\mu \mathrm{g} / \mathrm{L}$ & 34 & 0.066 & 0.73 & 0.34 & 4.5 & 16 & $0 \%$ \\
\hline Lithium & $\mu \mathrm{g} / \mathrm{L}$ & 34 & 3.6 & 1,593 & 88 & 21,300 & 24 & $0 \%$ \\
\hline Manganese & $\mu \mathrm{g} / \mathrm{L}$ & 34 & 1.0 & 485 & 59 & 4,230 & 25 & $6 \%$ \\
\hline Mercury (dimethyl) & $\mathrm{ng} / \mathrm{L}$ & 18 & $<0.005$ & 0.013 & $<0.005$ & 0.055 & 1 & $61 \%$ \\
\hline Mercury (monomethyl, diss.) & $\mathrm{ng} / \mathrm{L}$ & 18 & $<0.02$ & 0.59 & 0.079 & 6.7 & 31 & $22 \%$ \\
\hline Mercury (monomethyl, part.) & $\mathrm{ng} / \mathrm{L}$ & 18 & $<0.02$ & 0.037 & 0.024 & 0.11 & 30 & $39 \%$ \\
\hline Mercury (total, dissolved) & $\mathrm{ng} / \mathrm{L}$ & 18 & 0.38 & 6.8 & 2.0 & 28 & 9 & $0 \%$ \\
\hline Mercury (total, particulate) & $\mathrm{ng} / \mathrm{L}$ & 18 & $<1.0$ & 57 & 25 & 254 & 2 & $17 \%$ \\
\hline Molybdenum & $\mu \mathrm{g} / \mathrm{L}$ & 34 & 29 & 3,516 & 473 & 34,000 & 16 & $0 \%$ \\
\hline Nickel & $\mu \mathrm{g} / \mathrm{L}$ & 34 & 0.33 & 35 & 6.4 & 380 & 7 & $0 \%$ \\
\hline Selenium (IV) & $\mu \mathrm{g} / \mathrm{L}$ & 27 & $<0.1$ & 14 & 1.7 & 237 & 23 & $33 \%$ \\
\hline Selenium (total) & $\mu \mathrm{g} / \mathrm{L}$ & 34 & 0.30 & 217 & 15 & 2,360 & 9 & $0 \%$ \\
\hline Selenium (VI) & $\mu \mathrm{g} / \mathrm{L}$ & 27 & $<0.25$ & 125 & 1.8 & 1,180 & 9 & $30 \%$ \\
\hline Silica & $\mu \mathrm{g} / \mathrm{L}$ & 34 & 180 & 4,499 & 3,960 & 13,600 & 16 & $0 \%$ \\
\hline Silver & $\mu \mathrm{g} / \mathrm{L}$ & 34 & $<0.25$ & 0.35 & $<0.25$ & 1.69 & core 1 & $62 \%$ \\
\hline Strontium & $\mu \mathrm{g} / \mathrm{L}$ & 34 & 19 & 3,271 & 1,275 & 17,400 & 7 & $0 \%$ \\
\hline Thallium & $\mu \mathrm{g} / \mathrm{L}$ & 34 & $<0.1$ & 1.7 & $<0.5$ & 15 & 32 & $59 \%$ \\
\hline Uranium & $\mu \mathrm{g} / \mathrm{L}$ & 34 & $<0.002$ & 4.8 & 1.2 & 61 & 23 & $3 \%$ \\
\hline Vanadium & $\mu \mathrm{g} / \mathrm{L}$ & 34 & 0.50 & 254 & 26 & 3,950 & 10 & $0 \%$ \\
\hline Zinc & $\mu \mathrm{g} / \mathrm{L}$ & 34 & 1.9 & 19 & 10 & 124 & 24 & $0 \%$ \\
\hline \multicolumn{9}{|l|}{ Field Parameters } \\
\hline Dissolved Oxygen & $\%$ & 31 & 0.10 & 9.0 & 4.5 & 39 & $1 / 22$ & $0 \%$ \\
\hline Electrical Cond. & $\mathrm{mS} / \mathrm{cm}$ & 31 & 0.61 & 3.9 & 2.9 & 13 & $21 / 9$ & $0 \%$ \\
\hline ORP & $\mathrm{mV}$ & 31 & -260 & 9.6 & 49 & 184 & $31 / 5$ & $0 \%$ \\
\hline $\mathrm{pH}$ & $\mathrm{SU}$ & 31 & 6.2 & 8.6 & 8.5 & 12 & $7 / 16$ & $0 \%$ \\
\hline Temperature & ${ }^{\circ} \mathrm{C}$ & 31 & 14 & 21 & 20 & 36 & $32 / 19$ & $0 \%$ \\
\hline
\end{tabular}

1. Statistics exclude sample 11, duplicates, and QC samples.

2. Indicates the sample with the highest value. Low / high samples are indicated for field parameters. 


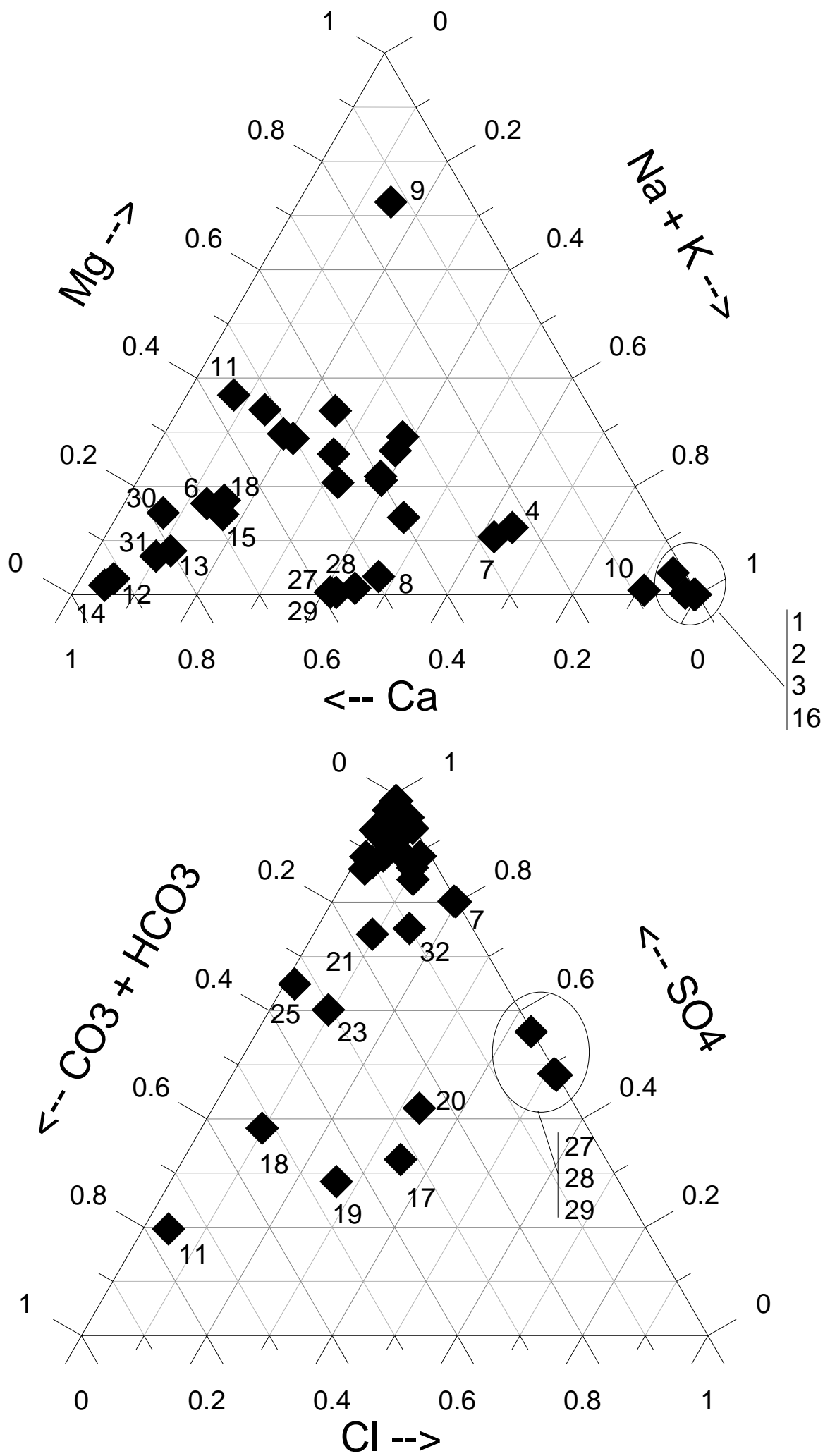

Figure 4-1

Ternary Plot Showing Relative Percentages of Major Constituents in the 2003 Samples 
Speciation data for arsenic, selenium, and chromium are still being developed due to discrepancies in the sum of species and total concentrations. Some of the 2003 sites were resampled in 2004 to evaluate possible influence of preservatives and holding times on the samples, particularly for arsenic and selenium. The efforts to resolve these discrepancies are discussed in Appendix A.

\section{Comparison of Ash Leachate Concentrations to Site Attributes}

Leachate concentrations for sites managing only ash were compared using box-whisker plots (Figure 4-2), which graphically show the distribution of concentrations for a given group of data. Non-detect values were plotted at their detection limit.

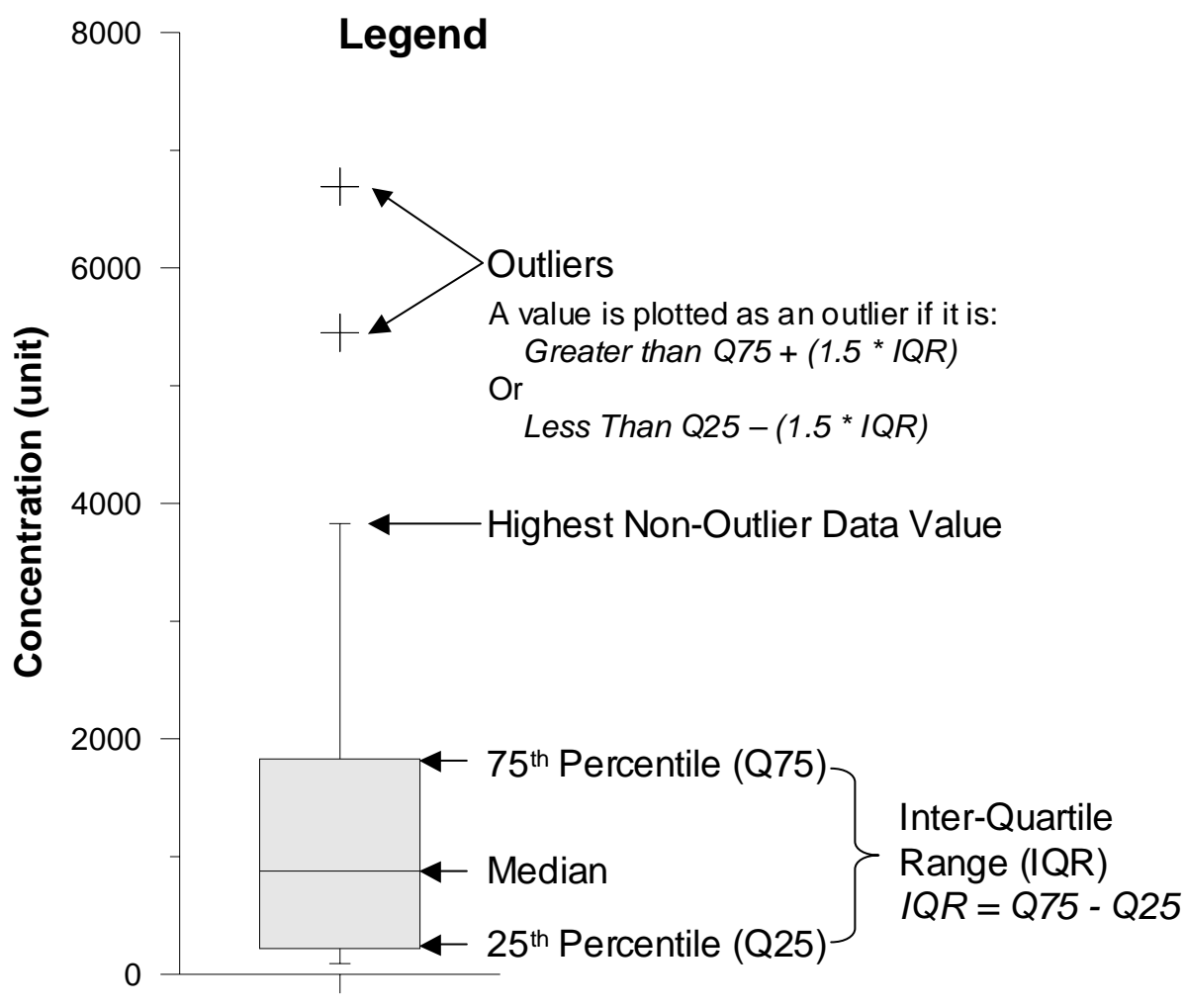

\section{Figure 4-2}

Legend for Box-Whisker Plots

Because there are only six samples of leachate from FGD solids, which came from two sites, and because FGD leachate is expected to be considerably different from fly ash leachate, these samples were not grouped with the fly ash samples in this comparison. The single spray dryer ash sample was similarly not grouped with the fly ash samples. 


\section{Major Constituents}

As previously stated in the summary for all data, the 2003 ash leachate samples were dominated by sulfate, calcium, and sodium (Figure 4-3). Concentrations of all major ions, except chloride, were higher in landfill leachate than in impoundment leachate (Figure 4-4). This relationship likely reflects washing of the ash particles that occurs during sluicing.

There was also a difference in major ion composition by source coal type (Figure 4-5). Sulfate, sodium, and potassium concentrations tended to be higher when the source coal was subbituminous, rather than bituminous. Conversely, calcium concentrations were higher when the source coal was bituminous.

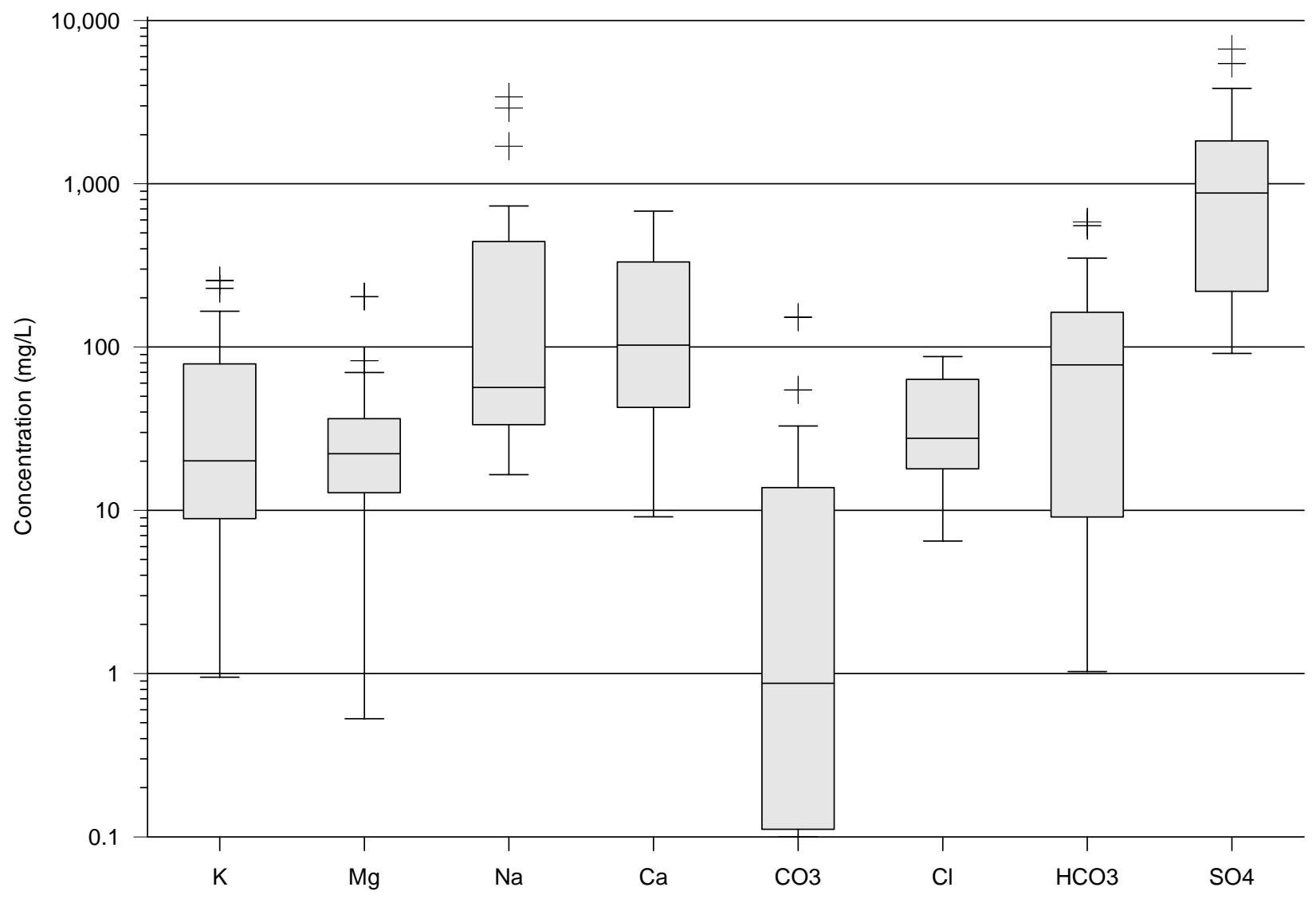

Figure 4-3

Box-Whisker Plot Showing Major Constituent Concentrations for All Coal Ash Samples. 

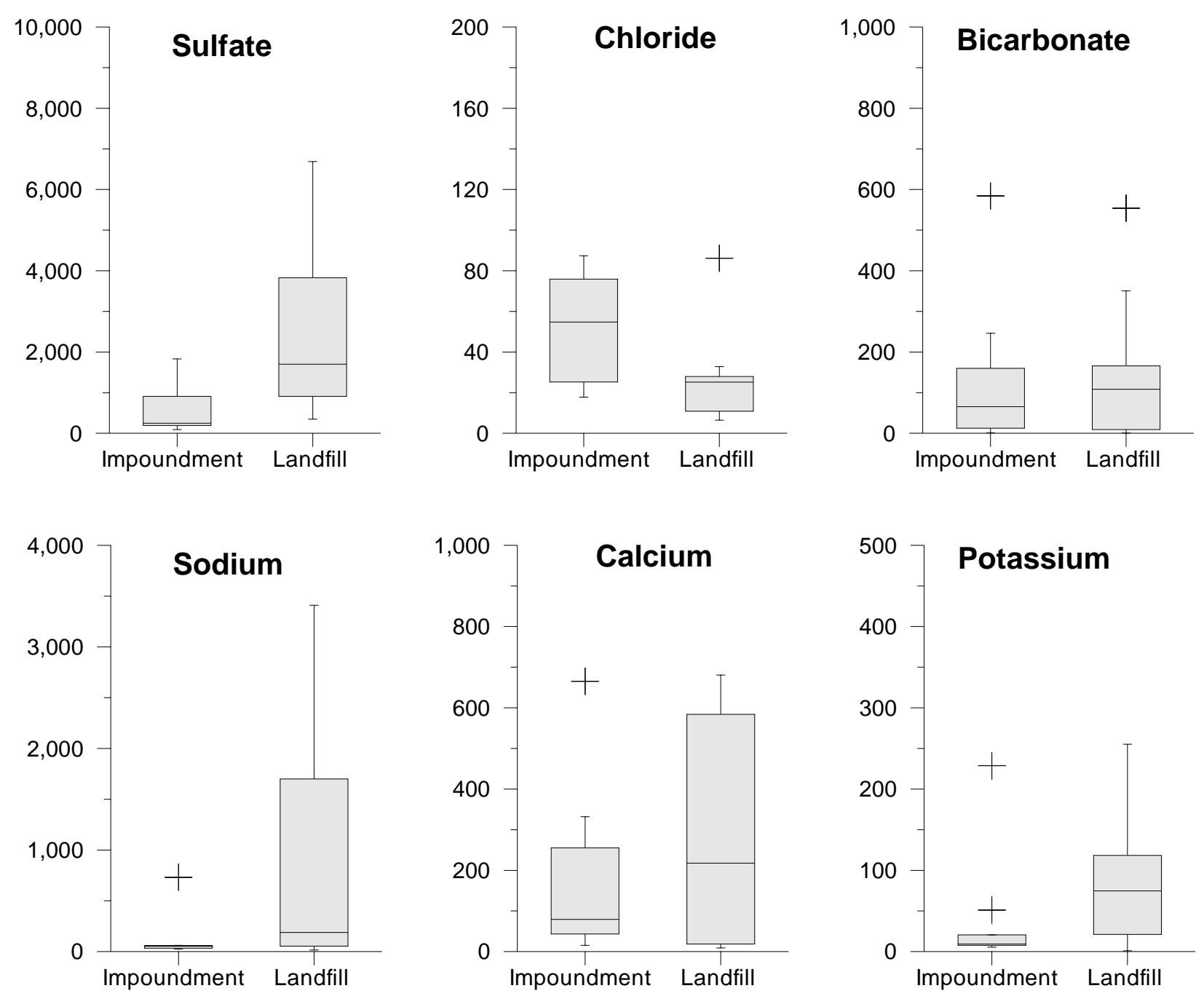

Figure 4-4

Box-Whisker Plot Comparing Major Constituent Concentrations in Coal Ash Landfill and Impoundment Leachate 

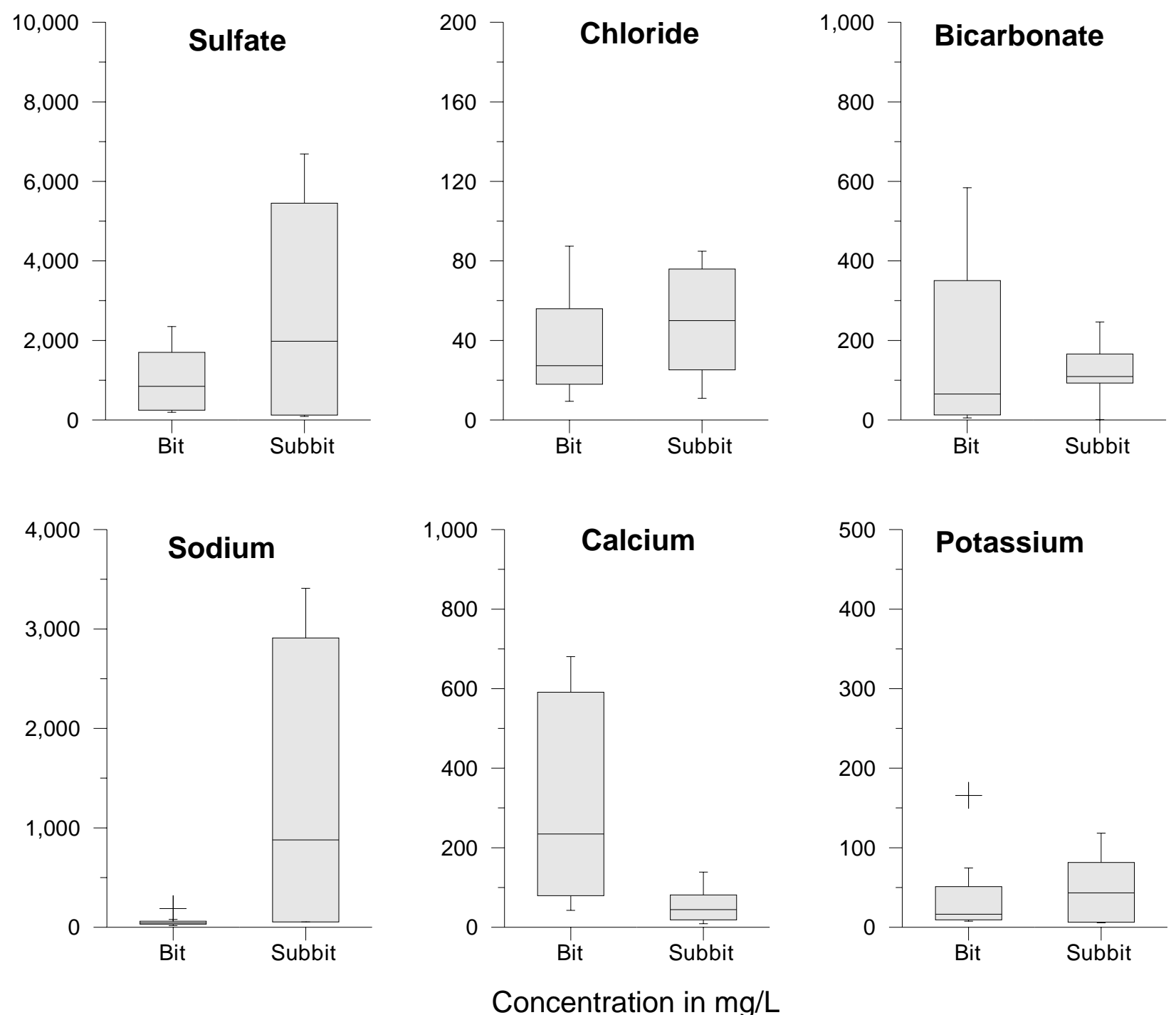

Figure 4-5

Box-Whisker Plot Comparing Major Constituent Concentrations in Coal Ash Leachate Derived from Bituminous and Subbituminous Coal 


\section{Minor and Trace Elements}

The interquartile range for most trace elements spanned almost an order of magnitude, and the range from the highest to the lowest values spanned two to three orders of magnitude in most cases (Figure 4-6). Twelve elements were selected for further comparison, due to their concentration in CCP leachate or regulatory significance.

Similar to the major constituents, most of the plotted minor and trace elements (aluminum, boron, lithium, molybdenum, strontium, vanadium, cadmium, mercury, and selenium) had higher concentrations in landfill leachate samples than in impoundment samples; antimony had higher concentration in impoundment leachate samples, and there was little difference for arsenic and nickel (Figure 4-7). Again, this difference may reflect washing of ash as it is sluiced to the impoundments.

Source coal type also affects minor and trace constituent concentrations. Coal ash from subbituminous coals had higher concentration ranges for aluminum, molybdenum, vanadium, cadmium, mercury, and selenium, while ash from bituminous coals yielded higher leachate concentrations for boron, lithium, strontium, arsenic, antimony, and nickel (Figure 4-8).

These comparisons highlight how CCP management methods and source coal type can influence leachate chemistry, although there are likely interrelationships between these broad categories. The current data set is not sufficiently large to explore these interrelationships; therefore, this analysis will be completed after the 2004/2005 sample results are available. 

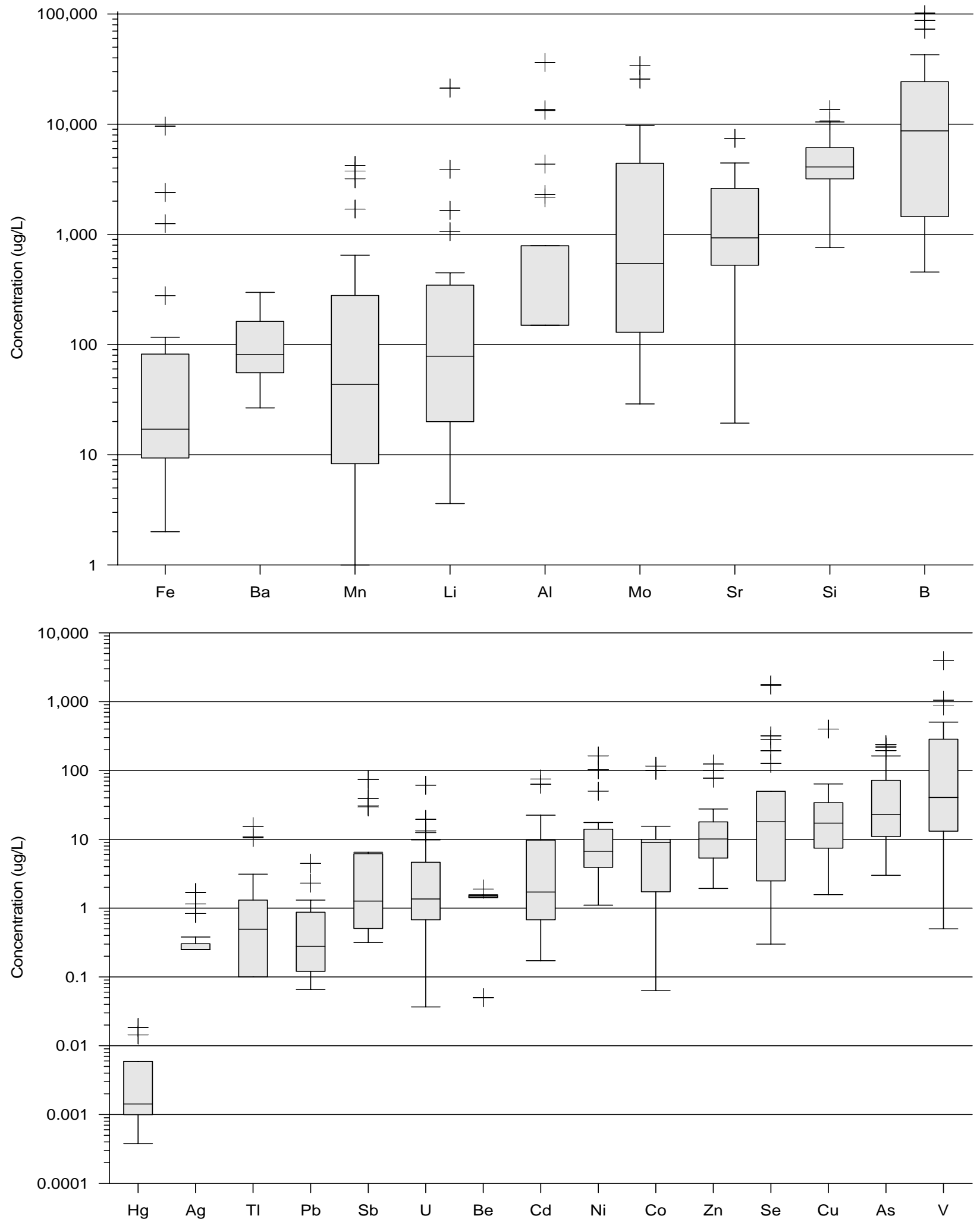

Figure 4-6

Box-Whisker Plot Showing Ranges of Minor and Trace Elements in Coal Ash Leachate 

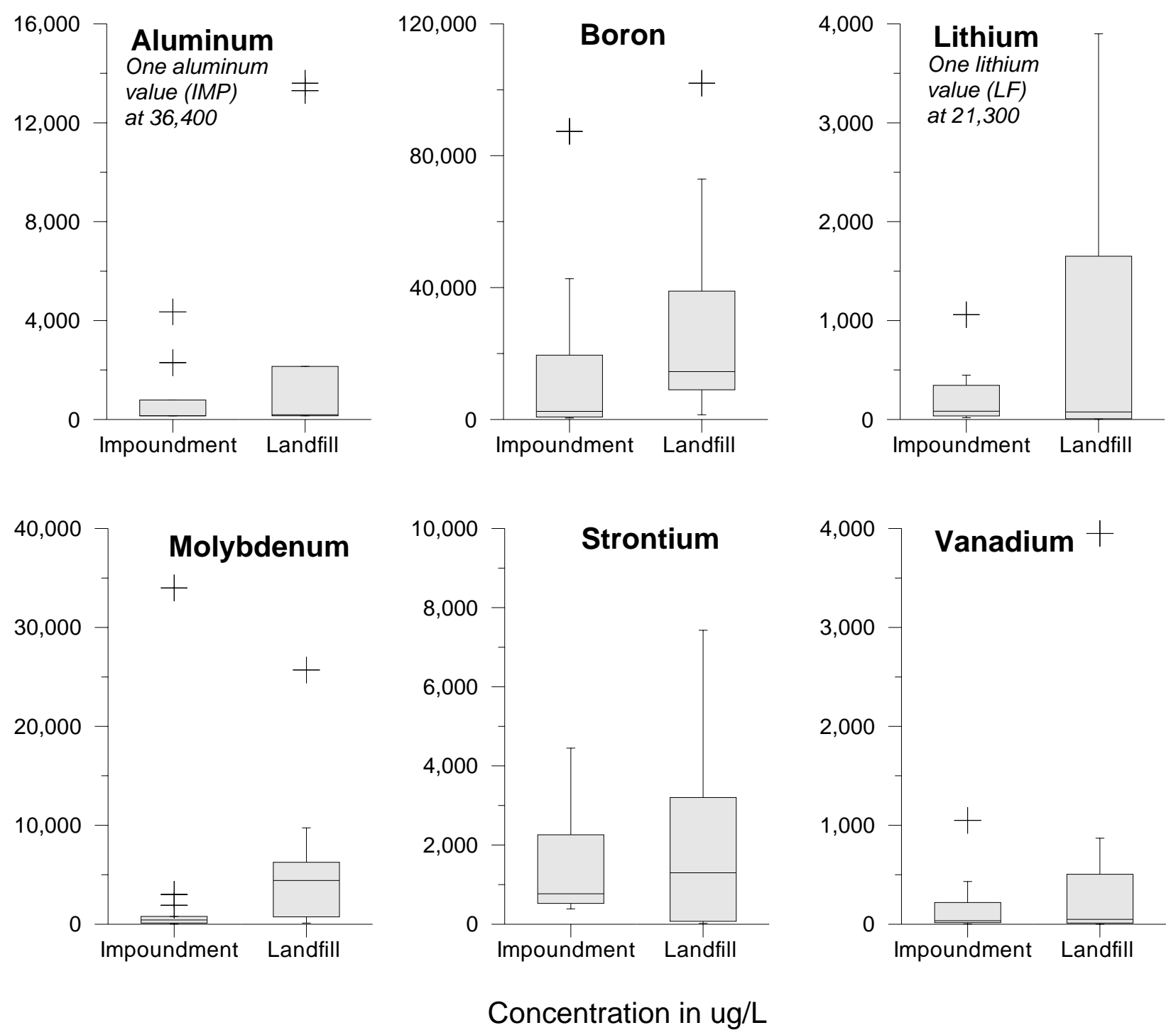

Figure 4-7a

Box-Whisker Plot Comparing Minor/Trace Element Concentrations in Coal Ash Landfill and Impoundment Leachate 

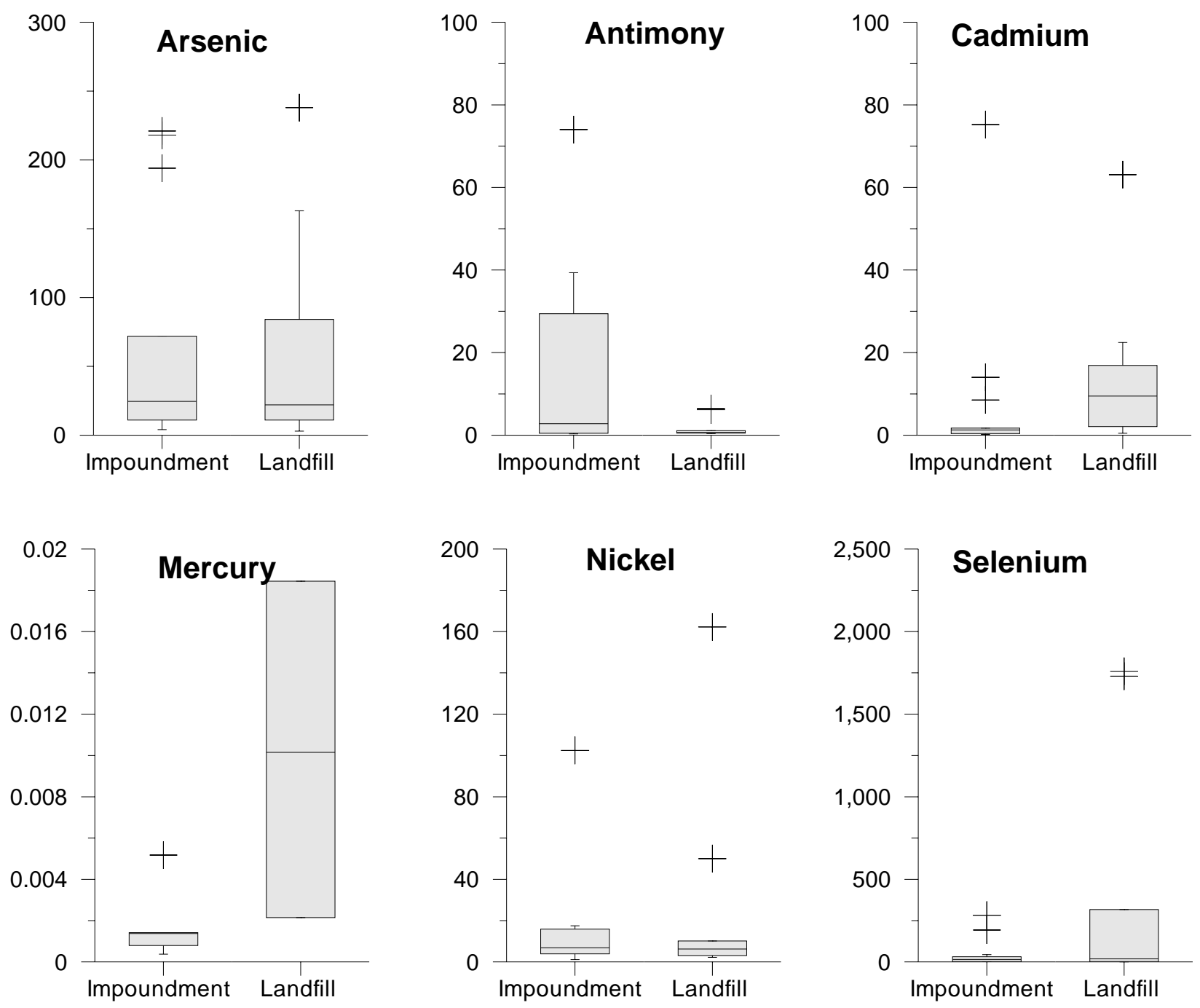

Concentration in ug/L

Figure 4-7b

Box-Whisker Plot Comparing Minor/Trace Element Concentrations in Coal Ash Landfill and Impoundment Leachate 

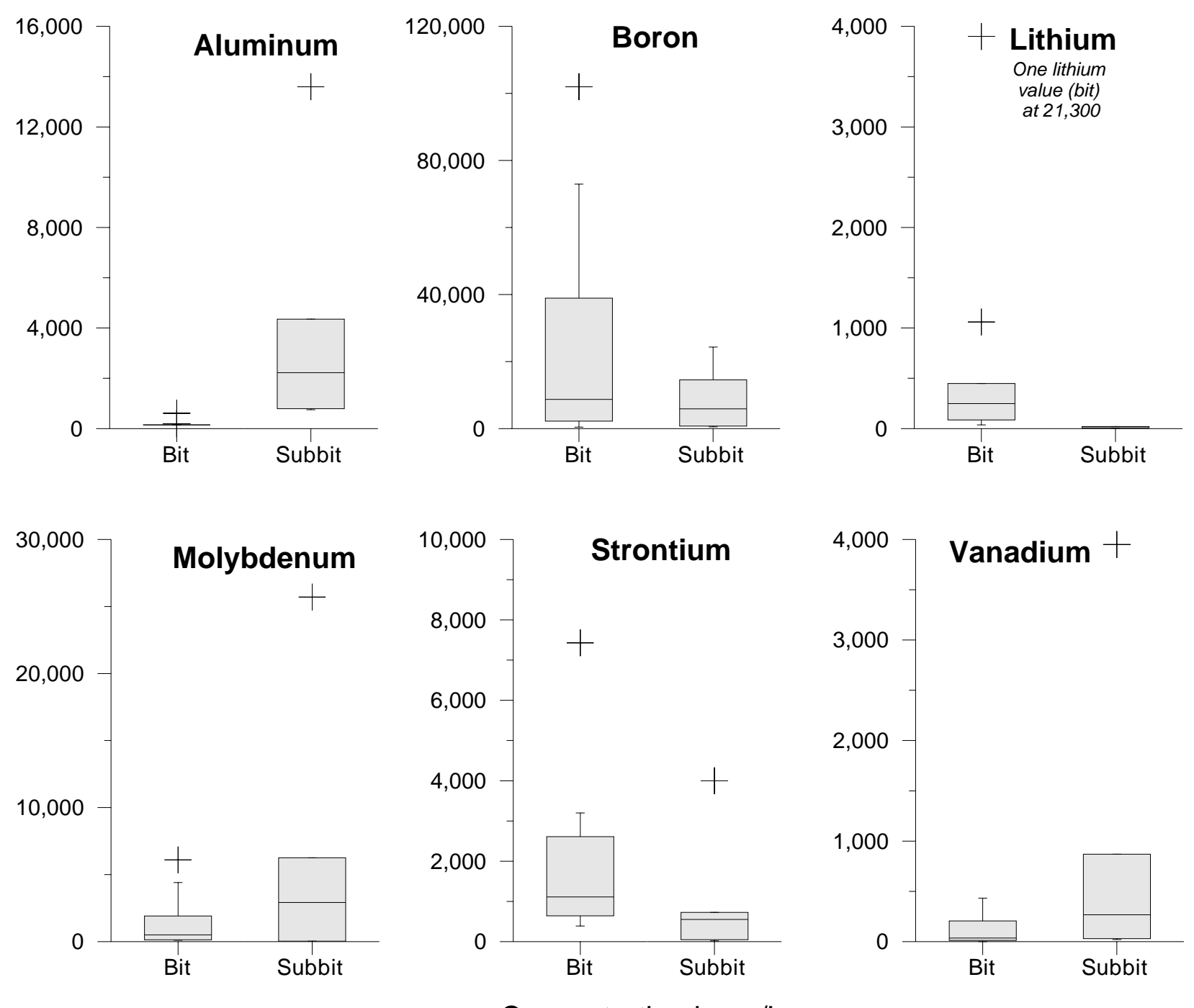

Figure 4-8a

Box-Whisker Plot Comparing Minor/Trace Element Concentrations in Coal Ash Leachate Derived from Bituminous and Subbituminous Coal 

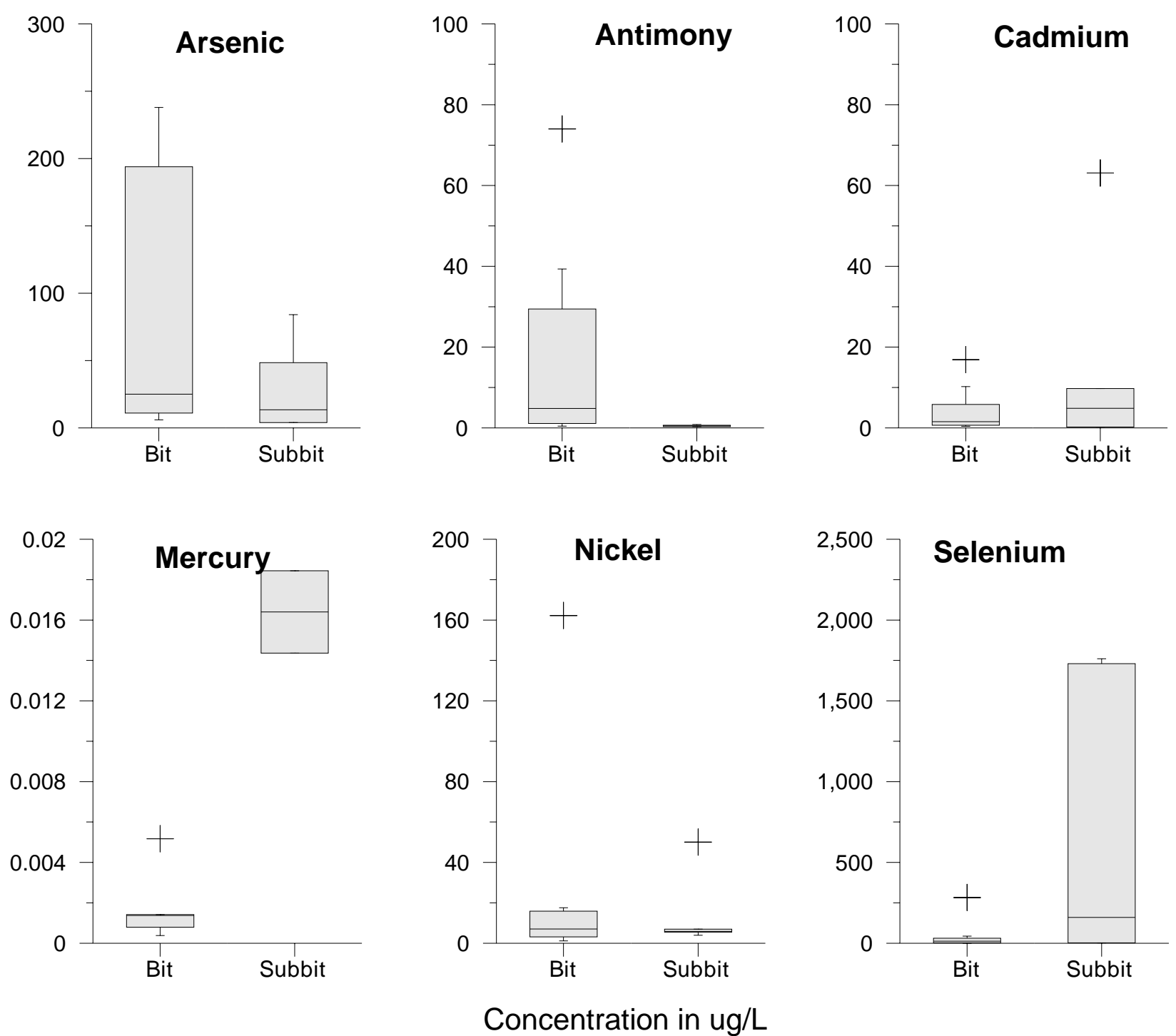

Figure 4-8b

Box-Whisker Plot Comparing Minor/Trace Element Concentrations in Coal Ash Leachate Derived from Bituminous and Subbituminous Coal 


\section{Field Parameters}

The $\mathrm{pH}$ of the leachate samples was neutral to strongly alkaline. Leachate from landfills (Figure 4-9) and ash derived from subbituminous coal (Figure 4-10) tended to be more alkaline than impoundment/bituminous coal leachate. Dissolved oxygen and ORP were lower in landfills than in impoundments. Reflecting major ion concentrations, specific conductance tends to be higher in landfill leachate than in impoundment leachate, and for ash leachate from subbituminous coal rather than bituminous coal. TOC and TIC concentrations were higher in leachate from landfills than in impoundments. Results for these two parameters were mixed when comparing source coals.
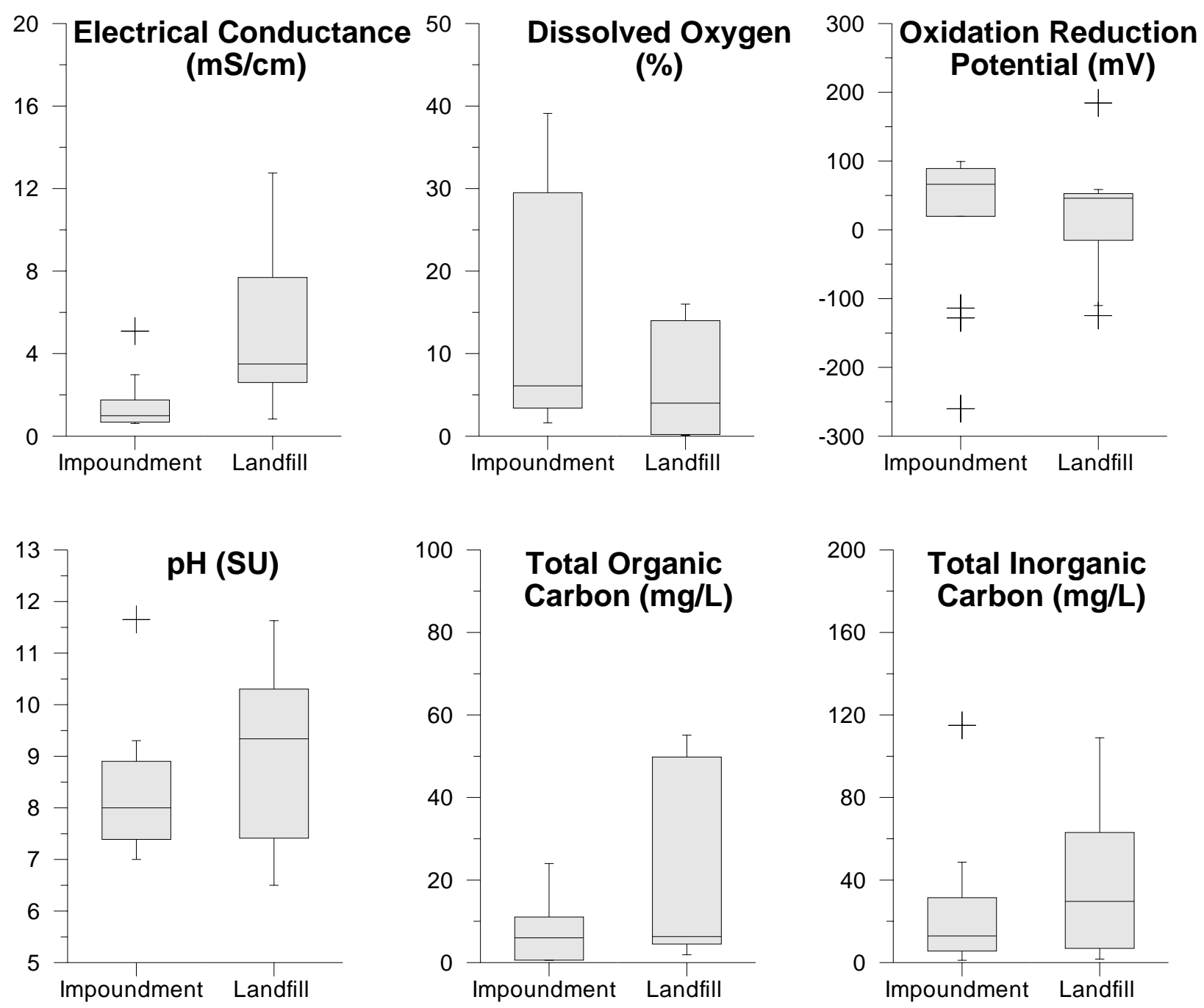

Figure 4-9

Box-Whisker Plot Comparing Field Parameters in Coal Ash Landfill and Impoundment Leachate 

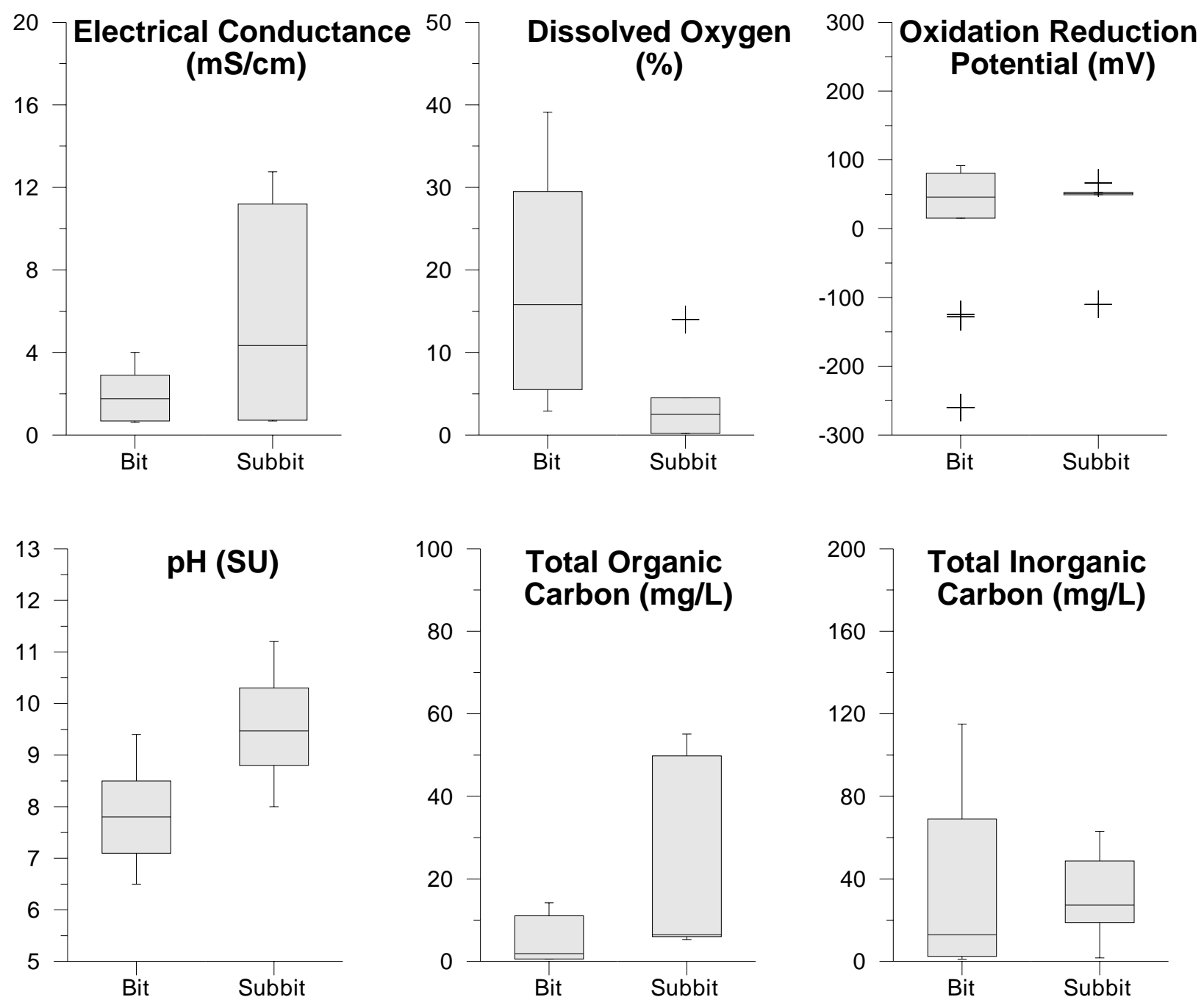

Figure 4-10

Box-Whisker Plot Comparing Field Parameters in Coal Ash Leachate Derived from Bituminous and Subbituminous Coal 


\section{Leachate Variability as a Function of Sample Point}

Leachate samples were collected from a variety of sample points such as wells at landfills and impoundments, leachate collection systems at landfills, and the ash/water interface at impoundments. Potential differences between sample points were reviewed by comparing the range of total dissolved solids concentrations and sum of trace elements for samples collected at each point (Figures 4-11 and 4-12).

Total dissolved solids (TDS) values were calculated by summing the concentrations of all constituents analyzed. Median TDS concentrations were highest in samples from lysimeters, leachate collection systems, and leachate wells, and lowest in samples from pond outfalls, sluice lines, and the ash/water interface (Figure 4-11). Minor and trace element concentrations, primarily driven by boron, were highest in leachate well, lysimeter, and soil boring ${ }^{4}$ samples, and lowest in outfall, seep, and sluice line samples (Figure 4-12). In both cases, there is a tendency for concentrations in leachate porewater to be higher than for leachate pond water.

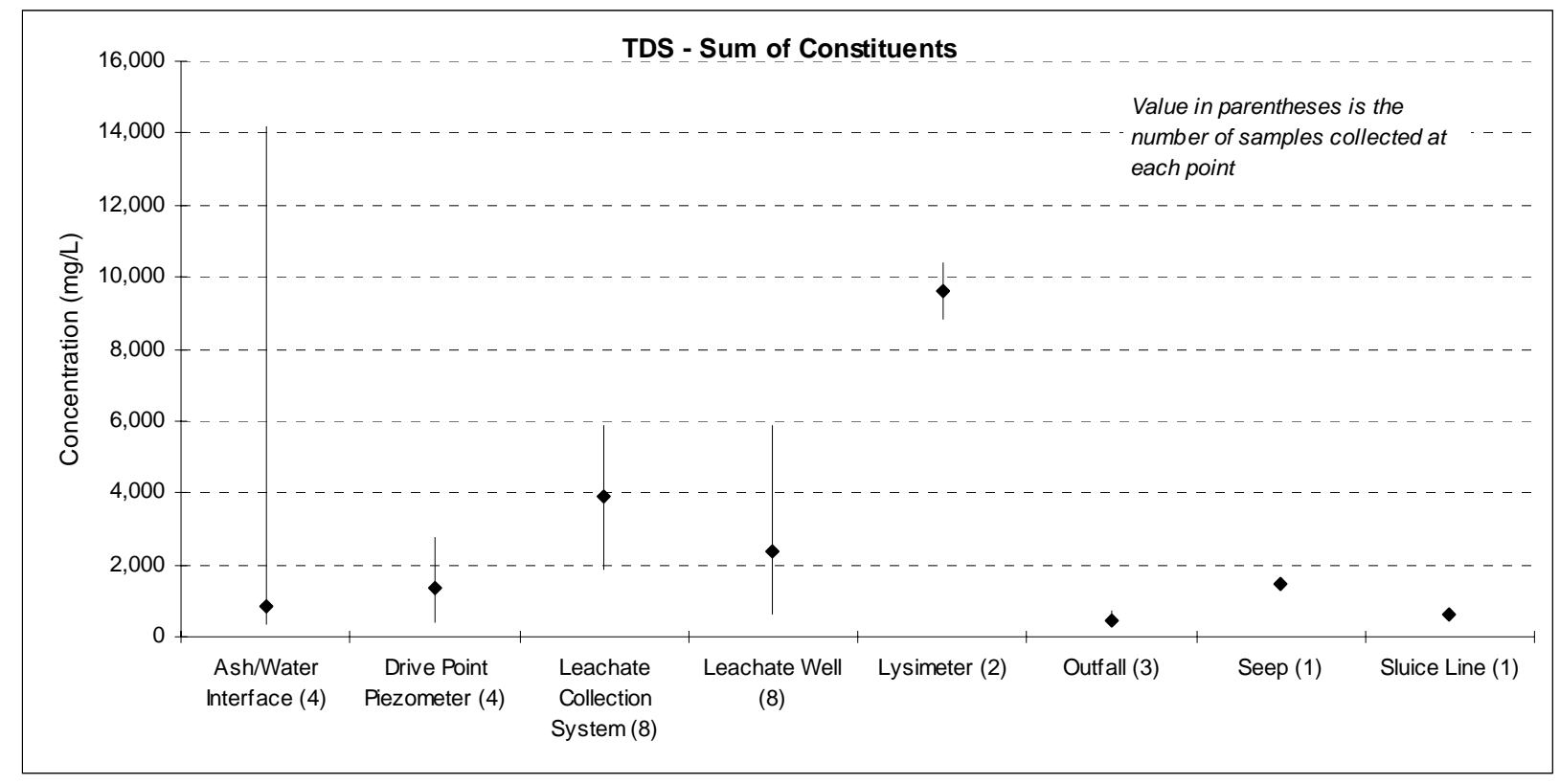

Figure 4-11

Range and Median of Total Dissolved Solids Concentrations by Sample Collection Point

\footnotetext{
${ }^{4}$ Major constituent concentrations were not determined for core samples; therefore TDS concentrations could not be calculated.
} 


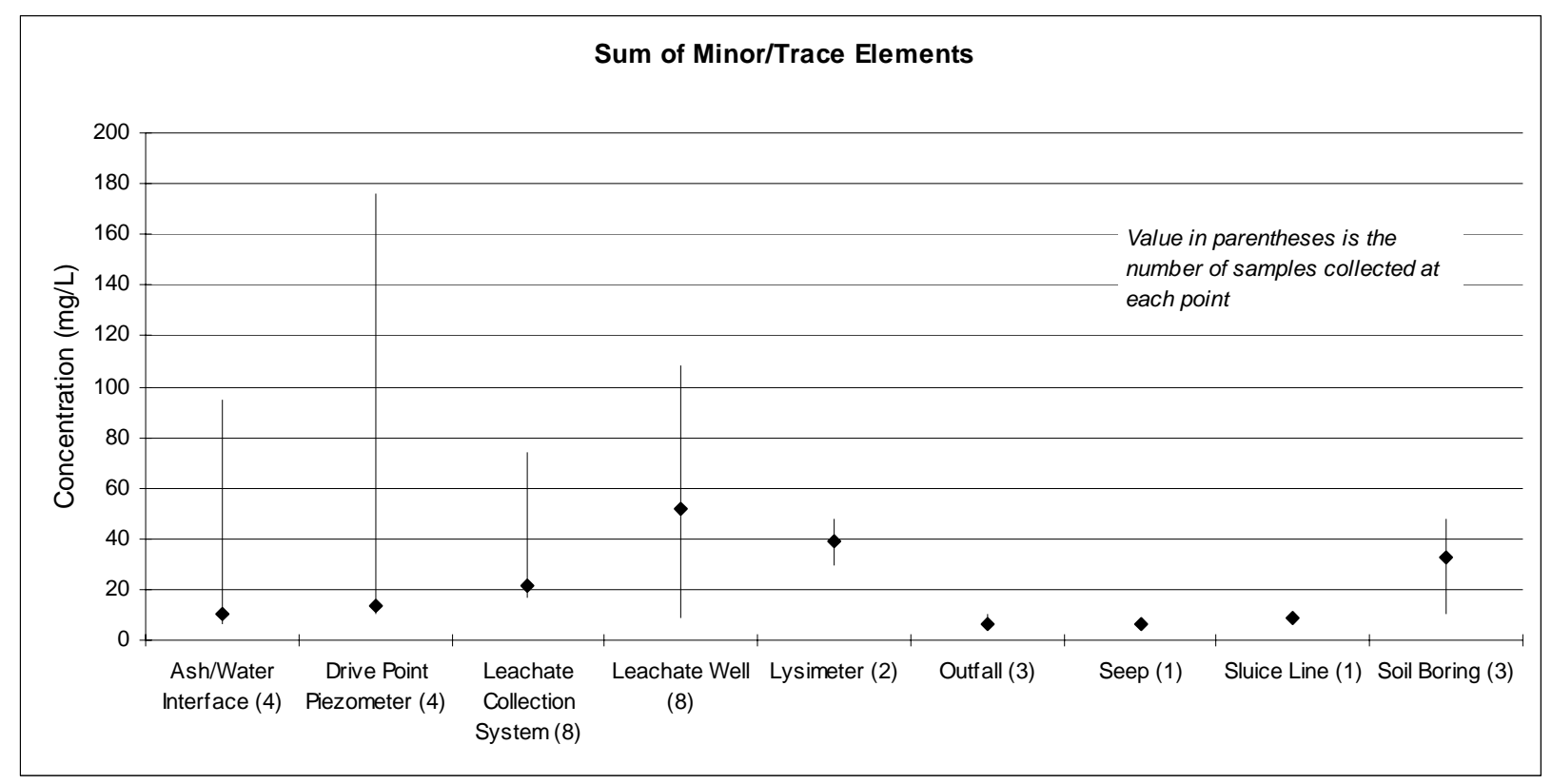

Figure 4-12

Range and Median of Sum of Minor/Trace Elements by Sample Collection Point

As follow-up to these observations, different sampling points within the same site were compared to determine whether or not there was a difference between pond water and porewater concentrations. Four sites had both porewater and pond water samples (CV2, JA1, SC2, and SX1). In three of the four cases, the porewater sample returned a higher TDS value, and a higher sum of minor/trace constituents value than the pond water samples (Table 4-2). This observation suggests that additional leaching may occur as pond water equilibrates with the sediments in an impoundment.

Table 4-2

Comparison of Pond Water and Porewater Leachate Samples

\begin{tabular}{|l|c|c|c|c|c|}
\hline & \multicolumn{3}{|c|}{ Pond Water Samples } & \multicolumn{2}{c|}{ Porewater Samples } \\
\hline Site & Seep & Outfall & $\begin{array}{c}\text { Ash/Water } \\
\text { Interface }\end{array}$ & $\begin{array}{c}\text { Drive Point } \\
\text { Piezometer }\end{array}$ & Leachate Well \\
\hline Total Dissolved Solids & \multicolumn{3}{|l|}{} \\
\hline CV2 & 1,454 & 733 & & 2,754 & \\
\hline JA1 & 359 & 362 & $379 / 595$ & \\
\hline SC2 & & 14,200 & & $3,775 / 5,875$ \\
\hline SX1 & & 1,268 & 2,164 & \\
\hline Sum of Minor/Trace Elements & & & 17 & \\
\hline CV2 & 6.4 & 10 & & $10 / 11$ & \\
\hline JA1 & 6.1 & 6.6 & 176 & \\
\hline SC2 & & 95 & & \\
\hline SX1 & & 14 & & \\
\hline
\end{tabular}




\section{5}

\section{REFERENCES}

EPRI, 1994. Chemical Attenuation Reactions of Selenium, Palo Alto, CA, Report TR-103535.

EPRI, 2000. Environmental Chemistry of Arsenic: A Literature Review, Palo Alto, CA, Report 100585.

EPRI, 2003a. Combustion By-Product Environmental Analysis System, Palo Alto, CA, Report 1005263.

EPRI, 2003b. Field Evaluation of Comanagement of Utility Low-Volume Wastes with HighVolume By-Products: MO Site, Palo Alto, CA, Report 1005267.

EPRI, 2004. Chemical Attenuation Coefficients for Arsenic Species Using Soil Samples from Selected Power Plant Sites, Palo Alto, CA, Report 1005505.

Gürleyük, H. and D. Wallschläger, 2001. Determination of Chromium Species Using Suppressed Ion Chromatography-Inductively-Coupled Plasma-Mass Spectrometry, J. Anal. At. Spectrom. 16, 926-930.

Hintelmann, H. and N. Ogrinc, 2003. Determination of Stable Mercury Isotopes by ICP/MS and Their Application in Environmental Studies, in: Cai, Y. \& Braids, O.C. (eds.): Biogeochemistry of environmentally important trace elements, ACS Symposium Series 835, American Chemical Society, 321-338.

Lindberg, S.E., G. Southworth, E.M. Prestbo, D. Wallschläger, M.A. Bogle, and J. Price, 2004. Gaseous Methyl- and Inorganic Mercury in Landfill Gas from Landfills in Florida, Minnesota, Delaware and California, accepted for publication in Atmos. Environ.

Puls, R.W and M.J. Barcelona, 1995. Low-Flow (Minimal Drawdown) Ground-Water Sampling Procedures, U.S. Environmental Protection Agency, EPA Ground Water Issue, EPA540-S-95504.

Wallschläger, D. and R. Roehl, 2001. Determination of Inorganic Selenium Speciation in Waters by Ion Chromatography-Inductively-Coupled Plasma-Mass Spectrometry Using Eluant Elimination with a Membrane Suppressor, J. Anal. At. Spectrom. 16, 922-925.

Wallschläger, D., R.T. Wilkin, and R.G. Ford, 2005. Soluble Arsenic-Thio Species in Sulfidic Waters, submitted to Environ. Sci. Technol. 


\section{$A$ \\ Appendix}

\section{Discrepancies in the Mass Balance of Arsenic, Selenium and Chromium Species}

If the speciation method is capable of determining all present species of a given element, then the sum of the independently determined species should equal the total dissolved concentration of this element. However, in practice, this "species mass balance" does not always add up, and there are a number of possible reasons for deviation from this ideal behavior, including (but not limited to):

- The measured total dissolved element concentration is systematically high or low.

- One or more measured concentration of the individual determined species is systematically high or low.

- There are species present in significant amounts that cannot be determined by the speciation method.

- There are significant losses of individual species during preservation or storage (we know from experience that this is not the case for the total element concentration).

The species mass balance was not satisfactory for many of the samples collected in 2003 . Three potential causes for this discrepancy have been identified and are discussed next.

\section{Irreversible Formation of Precipitates in the Speciation Samples}

In many of the 2003 samples, formation of significant amounts of a white-yellow precipitate was observed when the samples were thawed in a glovebox prior to analysis. It is important to understand that the cryofreezing preservation procedure was chosen to avoid potential speciation changes associated with the commonly used sample acidification preservation approach. Research conducted by Trent University demonstrates unequivocally that, in reducing waters containing free sulfide, acidification destroys reduced thio-species of arsenic and selenium, and either removes them from solution or converts them into oxy-species. This issue would be potentially problematic for a significant fraction of the 2003 samples. Sulfide is not measured for this project; however, several samples clearly smelled of sulfide during collection, and many fall into the Eh-pH range where sulfate reduction occurs. However, for the samples where reducing conditions were not encountered (which is the majority of the collected samples), acid preservation should yield the "correct" speciation results, and eliminate the formation of precipitates.

The precipitates did not re-dissolve when the sample was kept at room temperature for several days; therefore, this precipitation process appears to be irreversible. Also, since the samples were stored and thawed in the absence of air, sample oxidation can be excluded as a reason for the precipitation. Based on geochemical modeling using the known major element composition of the samples, it was assumed that the precipitates consist mostly of calcium minerals, particularly calcite $\left(\mathrm{CaCO}_{3}\right)$ and gypsum $\left(\mathrm{CaSO}_{4}\right)$. Researchers at Trent University attempted to re-create the formation of these precipitates by making model solutions mimicking several of the collected 
samples (in terms of major anions and cations), and subjecting these model solutions to freezing and thawing under various conditions, but precipitates were not observed. This leads to the conclusion that the formation of these precipitates was predominantly caused by the relatively long storage times for the 2003 speciation samples prior to analysis, which resulted from problems with the IC and ICP-MS equipment required for the speciation analyses. This theory is supported by the fact that no precipitates have been observed in any speciation samples collected in 2004, which were typically analyzed for speciation within two weeks after collection.

Since the sum of the measured species in many samples is significantly lower than the independently determined total dissolved element concentration, it was assumed that a fraction of the species was lost from solution by co-precipitation with these minerals. However, it is significant to note that similar discrepancies were also observed when no visible precipitate was formed, both in cryofrozen speciation samples and in the corresponding acid-preserved samples (from which the total dissolved element concentrations were determined) when these were analyzed for speciation.

To resolve this question, it will be necessary to isolate the precipitates, and determine if they contain significant amounts of the respective trace element(s). This will be investigated in the future; however it has not been attempted yet, because it involves chemical digestion methods that will likely alter the speciation of any trace elements bound to the precipitates (if that is indeed the case). Before attempting this task, all other potential explanations (see below) will be fully explored. Each collected speciation sample also has a parallel cryofrozen sample that has not yet been used for any purpose, so if a significant fraction of some trace element species is bound to the precipitates, this research avenue can be pursued by identifying the precipitates mineralogically, devising leaching/dissolution procedures that release the bound metal(loid) species from them without destroying their chemical identity (if that is possible), and then analyzing the parallel speciation samples using the new methods.

\section{Presence of Species that Cannot be Analyzed Using Current Methods}

Based on commonly accepted geochemical models, only two inorganic species for each of the three speciation elements are expected in the leachate samples: arsenite [As(III)] and arsenate [As(III)], selenite [Se(IV)] and selenate [Se(VI)], and trivalent chromium [Cr(III)] and chromate $[\mathrm{Cr}(\mathrm{VI})]$. The only other species routinely analyzed for are the organometallic compounds monoand dimethylarsenate, but due to the low biological activity expected in the types of waters studied here, it is unlikely that these would constitute a significant fraction of the total arsenic present. Therefore, the IC-ICP-MS methods should be capable of measuring all relevant dissolved arsenic, selenium, and chromium species in the collected samples. In support of this assumption, there was no evidence of any additional species for these elements in the 2003 samples (an unknown species would be detected because the ICP-MS will yield the same relative signal for any form of a trace element eluting from the IC column; however, its signal would appear at a different retention time than the known species).

The preceding discussion is limited to dissolved trace element species that can pass through the IC column. Therefore, there are two other possible explanations for the observed discrepancies: a fraction of the trace elements in the speciation samples is present either in a different physical state (since the samples were filtered in the field, geochemists would call this state "colloidal"), or in the form of a dissolved chemical species that does not pass through the IC column. The 
latter hypothesis could be tested by measuring the dissolved trace element concentrations in the speciation samples after they have been thawed in the glovebox, which will be performed. The presence of colloids is currently under investigation using ultrafiltration as a means of characterizing the size distribution of the trace elements in the samples; at this point, those studies are being hampered by blank issues and unspecific retention behavior on the ultrafiltration membranes.

\section{Systematic Analytical Bias}

The Trent University laboratory routinely performs matrix spike experiments as part of their QC protocol, and can demonstrate that there are no significant losses for any of the individual determined species by the fact that matrix spike recoveries are typically quantitative within the margin of analytical error. By contrast, a number of analytical interferences were observed that led to increased total element concentrations, particularly for arsenic and selenium, in some samples. However, all of these issues have been corrected in the data set reported here. Therefore, there is no reason to believe that this potential concern is a major factor in the observed species mass balance discrepancies.

\section{Interpretation of the Reported Speciation Patterns}

It is clear at this point that the speciation results reported here do not adequately characterize arsenic, selenium, and chromium speciation in the collected water samples: either the analytical methods "missed" one or more important species per element, or some fraction of the dissolved species has been "lost" during storage. In the first case, a major task becomes to prove this theory, and identify the "missing" trace element species, so that a better and complete understanding of biogeochemical cycling and potential management options for elevated arsenic, selenium, or chromium concentrations in particular settings can be obtained. However, this would mean that the reported concentrations for the "known" species are correct, even though they don't add up to the total trace element concentration.

In the second case, the reported species concentrations would be wrong, and it is unclear whether they would even have any qualitative meaning. This depends on whether both species of one element are removed from solution by the precipitation process to the same extent, or whether one species is removed preferentially (or exclusively). If the chemical identity of the precipitates were known, one could speculate on the relative removal rates for each metal(loid) species, but in the absence of that knowledge, it is impossible to say if the reported "remaining" speciation patterns in the thawed speciation samples are even somewhat representative of the native geochemical conditions. A preliminary geochemical analysis of the reported speciation data shows that in many samples, the measured speciation patterns do not correspond to thermodynamic equilibrium predictions based on $\mathrm{pH}$ and $\mathrm{Eh}$; however, this is not unusual, and has been observed in many studies where no species mass balance issues were reported.

\section{Chromium}

The main reason that the chromium speciation results appear incomplete is that $\mathrm{Cr}$ (III) has not yet been determined for the 2003 samples, because the derivatization capability was not available at the time. This will be remedied by re-analysis, but is relatively meaningless until the species mass balance issue has been resolved, at least for samples without precipitate formation (for the 
2004 samples, where no precipitates have been observed, $\operatorname{Cr}(\mathrm{III})$ and $\mathrm{Cr}(\mathrm{VI})$ have generally had good species mass balance). Total chromium concentrations agree very well between the two isotopes ${ }^{52} \mathrm{Cr}$ and ${ }^{53} \mathrm{Cr}$, as well as between the two different ICP-MS instruments that were used, so there is a high degree of confidence in the reported total chromium results. For many samples, $\mathrm{Cr}(\mathrm{VI})$ and total chromium agree quite well, and so the assumption that any reported discrepancy is caused by the presence of significant amounts of $\mathrm{Cr}(\mathrm{III})$ appears justified. It is especially noteworthy that in all cases where total chromium exceeds $5 \mu \mathrm{g} / \mathrm{L}$, there is a very strong correlation between $\mathrm{Cr}(\mathrm{VI})$ and total chromium (Figure A-1). This is not surprising, because $\mathrm{Cr}(\mathrm{VI})$ is very soluble under the hydrogeochemical conditions encountered in the collected samples, while $\mathrm{Cr}$ (III) should be almost insoluble.

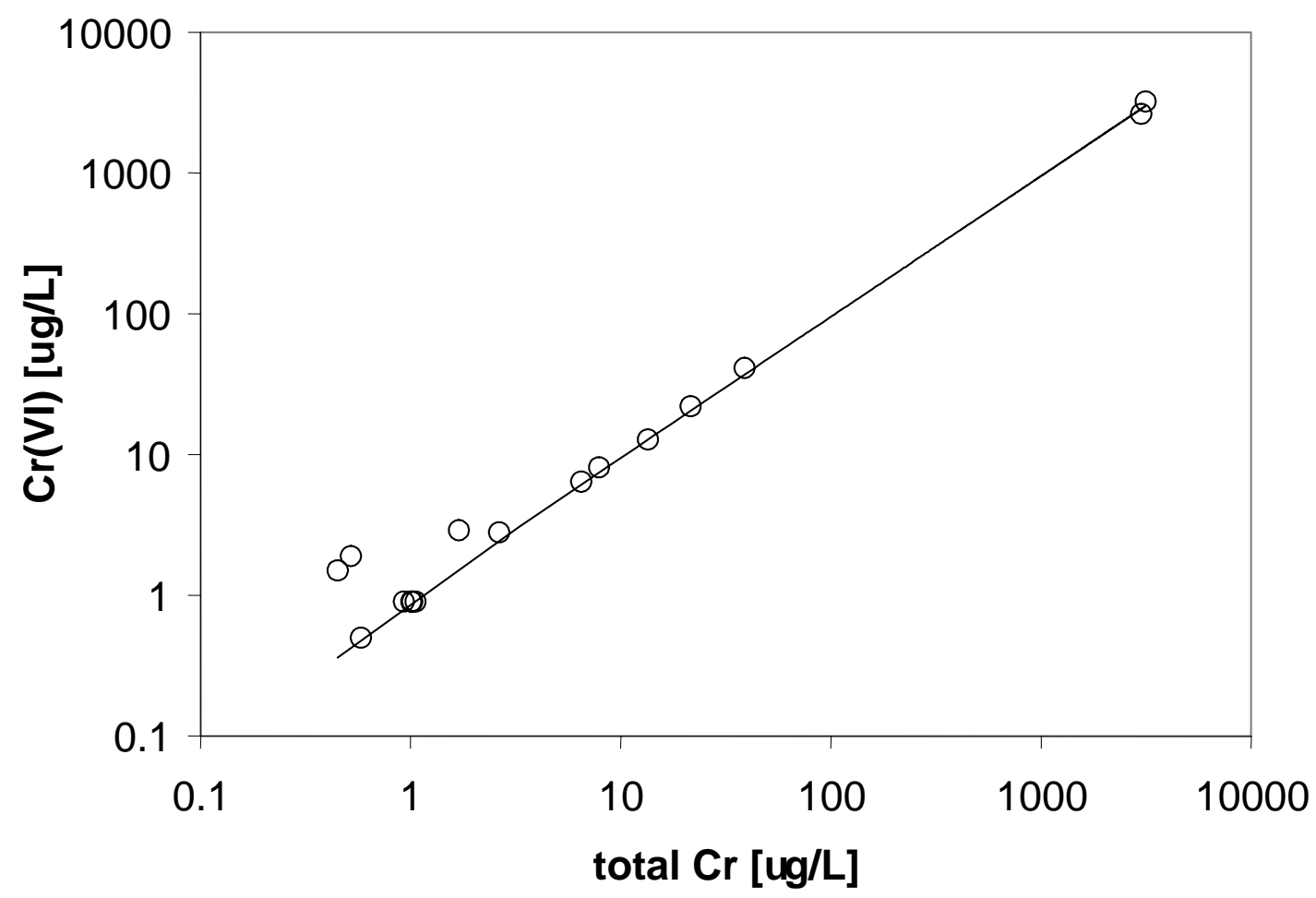

Figure A-1

Total Chromium vs Cr(VI) Concentrations in 2003 Samples

\section{Selenium}

Selenium speciation patterns show $\mathrm{Se}(\mathrm{VI})$ as the predominant species in 14 out of 22 samples in which at least one of the two selenium species was present above the detection limit. This is in sharp contrast to the speciation predicted for these samples based on their Eh-pH characteristics, which favors $\mathrm{Se}(\mathrm{IV})$ and (insoluble) $\mathrm{Se}^{0}$. Since $\mathrm{Se}(\mathrm{IV})$ is generally the more surface-reactive of the two selenium species, this finding supports the hypothesis that a significant fraction of $\mathrm{Se}(\mathrm{IV})$ was lost to the precipitates. The species recovery for Se was $36 \pm 36 \%$ (average \pm standard deviation). 


\section{Arsenic}

Arsenic speciation patterns show As(III) as the predominant species in 13 of the 17 samples in which at least one of the two arsenic species was present above the detection limit. This is in contrast to the speciation predicted for these samples based on their Eh-pH characteristics, which favors $\mathrm{As}(\mathrm{V})$ in most samples, although $\mathrm{As}(\mathrm{III})$ is predicted to dominate in certain samples. Since As(V) is generally the more surface-reactive of the two As species, this finding supports the hypothesis that a significant fraction of $\mathrm{As}(\mathrm{V})$ was lost to the precipitates. The species recovery for arsenic was $14 \pm 19 \%$ (average \pm standard deviation). 